\title{
1 Epigenetics of floral homeotic genes in relation to sexual dimorphism in the 2 dioecious plant Mercurialis annua
}

3

4 Janardan Khadka ${ }^{1}$, Narendra Singh Yadav $^{1 \dagger}$, Micha Guy ${ }^{1}$, Gideon Grafi ${ }^{1 *}$ and Avi Golan5 Goldhirsh $^{1^{*}}$

$6 \quad{ }^{1}$ French Associates Institute for Agriculture and Biotechnology of Drylands, Jacob Blaustein 7 Institutes for Desert Research, Ben-Gurion University of the Negev, Midreshet Ben Gurion 8 84990, Israel.

$9{ }^{\dagger}$ Present address: Department of Biological Sciences, University of Lethbridge, AB T1K $103 \mathrm{M} 4$, Canada.

$11 *$ To whom correspondence should be addressed

\section{Highlights}

15 Sex determination in Mercurialis aппиа is not related to epigenetics of floral homeotic genes 16 but appears to be modulated by an unknown gender-specific regulator(s) that affects hormonal 17 homeostasis. 
19

\section{Abstract}

In plants, dioecy characterizes species carrying male and female flowers on separate plants and occurs in about $6 \%$ of angiosperms. To date, the molecular mechanism(s) underlying sexual dimorphism is essentially unknown. The ability of gender-reversal by hormone application suggests that epigenetics might play an important role in sexual dimorphism. Proteome analysis of nuclei derived from flower buds of females, males and feminized males of the dioecious plant Mercurialis annua revealed differentially expressed proteins related to nucleic acid binding proteins, hydrolases and transcription factors, including floral homeotic genes. Further analysis showed that class B genes are mainly expressed in male flowers, while class D genes, as well as SUPERMAN-like genes, were mainly expressed in female flowers. Cytokinin-induced feminization of male plants was associated with down-regulation of malespecific genes concomitantly with up-regulation of female-specific genes. No correlation could be found between the expression of class B and D genes and their DNA methylation or chromatin conformation. Thus, our results ruled out epigenetic control over floral identity genes as the major determinants regulating sexual dimorphisms. Rather, determination of sex in $M$. аппиа might be controlled upstream of floral identity genes by a gender-specific factor that affects hormonal homeostasis.

\section{Key words}

Mercurialis annua, Dioecy, Floral homeotic gene, MADS-box gene, ABCDE model, SUPERMAN-like gene, Sex determination 


\section{Introduction}

The majority of angiosperms are hermaphrodites and monoecious (sexually monomorphic), whereby both male and female organs are found on the same individual plant. In contrast, only about $6 \%$ of the angiosperms are dioecious (sexually dimorphic) where male and female flowers are carried on separate individual plants (Renner and Ricklefs, 1995; Charlesworth, 2002). It has been hypothesized that dioecy has evolved independently from hermaphrodites through mutations in various families of plants (Charlesworth and Charlesworth, 1978; Charlesworth, 2002). Based on developmental aspects, dioecious plants are categorized into two types: type-I, unisexual flowers developed via abortion of reproductive organs that exhibit rudiments of the aborted organs, and type-II, to which Mercurialis annua belongs, where unisexual flowers do not have rudiments of the opposite sex (Mitchell and Diggle, 2005).

Most studies related to the regulation of flower development were performed in model plants such as Arabidopsis thaliana that has hermaphroditic flowers with four concentric whorls: sepals, petals, stamens and carpels. The homeotic genes that regulate the development of such flowers were described by the ABCDE model (Coen and Meyerowitz, 1991; Krizek and Fletcher, 2005). These gene classes were termed according to the whorl in which they function: class A genes APETALA1 (AP1) and APETALA2 (AP2), class B genes APETALA3 (AP3), TOMATO MADS-BOX GENE6 (TM6) and PISTILLATA (PI), class C gene AGAMOUS $(A G)$, class D genes SHATTERPROOF1 (SHP1), SHATTERPROOF2 (SHP2) and SEEDSTICK (STK) also known as AGAMOUS-like1 (AGL1), AGAMOUS-like5 (AGL5) and AGAMOUS-likel1 (AGL11), respectively, and class E genes SEPALATA1 (SEP1) to SEPALATA (SEP4). Most of these genes encode MIKC-type MADS-box domain containing transcription factors. The MADS-box proteins form homo- and/or heterodimers that bind specific DNA sequences, $\mathrm{CC}(\mathrm{A} / \mathrm{T})_{6} \mathrm{GG}$, called $\mathrm{CArG}$ box and the pairs of CArG-boxes are brought into close proximity by DNA looping (Nurrish and Treisman, 1995; Davies et al., 1996; Riechmann et al., 1996; Mendes et al., 2013). The protein dimers further form functionally active tetrameric protein complex termed, 'floral quartet', that specifically controls differentiation of flower whorls (Theissen and Saedler, 2001; Smaczniak et al., 2012). Accordingly, combination of $A+E$ genes specify sepals, $A+B+E$ genes specify petals, 
$\mathrm{B}+\mathrm{C}+\mathrm{E}$ genes specify stamens, $\mathrm{C}+\mathrm{E}$ genes specify carpels and $\mathrm{D}+\mathrm{E}$ genes specify ovule identity (Theissen and Saedler, 2001; Soltis et al., 2007).

As floral homeotic MADS-box genes control the expression of other regulatory genes, these genes are considered as key factors for development of the floral organs, both perianth parts and sex organs (Wuest et al., 2012; O'Maoileidigh et al., 2013; Stewart et al., 2016). However, the regulation of these genes is not fully understood. In Arabidopsis, SUPERMAN (SUP) is required for proper development of the reproductive organs inasmuch as mutation of the SUP gene has led to extra stamens formation at the expense of carpel development (Jacobsen and Meyerowitz, 1997; Sakai et al., 1995). The SUP transcription factor is proposed to act as a negative regulator of class B genes (i.e., AP3 and PI) to maintain boundaries between the stamen and the carpel whorls (Bowman et al., 1992; Yun et al., 2002; Prunet et al., 2017) and its role appears to be conserved among dicot and monocot plants (Nandi et al., 2000). Additionally, SUP gene is required for development of the outer integument of the ovule (Gaiser et al., 1995). In dioecious Silene latifolia, SUPERMAN orthologous gene, SlSUP was associated with female flower development (Kazama et al., 2009). Ectopic expression of SUP in tobacco plants was shown to induce increased feminization via enhancing cytokinin related processes (Nibau et al., 2011). A recent report addressing gender-specific methylation in the sex determining region of Populus balsamifera identified the PbRR9 gene showing a clear pattern of gender-specific methylation. PbRR9 encode for a protein member of the two-component response regulator (type-A) gene family involved in cytokinin signaling (Brautigam et al., 2017).

Only limited research has been made to elucidate the role of floral homeotic genes in sexually dimorphic dioecious plants. This is surprising in view of the apparent advantage of separation of the reproductive organs between female and male plants, which makes it experimentally more amenable to investigation of the developmental regulation of each gender in plants. We have shown recently dimorphic responses of $M$. annua plant genders to stress that may be attributed to female plants' capacity to survive stress and complete the reproductive life cycle (Orlofsky et al., 2016). A few of the more studied dioecious species include Silene latifolia and Rumex acetosa of the type-I flowers and Thalictrum dioicum and Spinacia oleracea of the type-II flowers. It was shown that in the case of S. latifolia and $R$. acetosa, class B and C floral organ identity genes are expressed early in development of male and female flowers (Hardenack et al., 1994; Ainsworth et al., 1995), while in T. dioicum and 
103

104

105

106

107

108

109

110

111

112

113

114

115

116

117

118

119

120

121

122

123

124

125

126

127

128

129

S. oleracea, class B and C genes are differentially expressed at floral initiation (Di stilio et al., 2005; Pfent et al., 2005). Sather et. al. (2010) showed that silencing of class B genes in $S$. oleracea is able to alter the floral gender of males into hermaphrodites or females due to transformation of stamens into carpels.

The annual dioecious (type-II) M. апnиa L. (Euphorbiaceae) is a unique model plant for the study of dioecism, since it has a short life cycle, which enables molecular-genetic studies, in contrast to most dioecious plants, which are woody perennials. It is a common roadside herb native to the drought and high-sunlight prone Mediterranean basin, which has spread into Europe, North America and Australia (Durand and Durand, 1991; Pannell et al., 2008). The diploid species $(2 \mathrm{n}=16)$ is a strictly dioecious, while polyploid species are not (Thomas, 1958; Durand and Durand, 1991; Pannell et al., 2008). The dioecious M. апnиa has an interesting genetic system of sex determination lacking heteromorphic sex chromosome. Identification of male specific molecular markers and recent genetic analyses have revealed that males possess homomorphic XY chromosomes, but the molecular mechanism of sex determination is not clear yet (Khadka et al., 2002, 2005; Russell and Pannell, 2015; Veltsos et al., 2018). Furthermore, sex expression in M. аппиа can be reversed by exogenously applied plant growth hormones. Accordingly, auxins have a masculinizing effect while cytokinins have a feminizing effect (Delaigue et al., 1984). The ability of gender-reversal by hormone application suggests that the gene(s) required for the development of both type of flowers are genetically functional but might be restrained by epigenetic means in the floral primordia, even when lacking vestiges of the opposite sex, thus being still sexually bi-potent.

Here we attempted to study the epigenetic regulation of floral identity genes in $M$. аппиа and the relationship with sex determination. We report that differential expression of floral homeotic genes was associated with sexual dimorphism in M. annua and cytokinin was involved in their transcriptional control. The possible involvement of epigenetic regulation of the examined floral genes was ruled out. 


\section{Plant growth condition}

132

Dioecious Mercurialis annua (Euphorbiaceae), Belgian origin, was used in this study. Seeds were sown in trays containing standard gardening soil and the seedlings were transplanted into pots $(2.5 \mathrm{~L})$ and grown in a controlled climate growth chamber at $27{ }^{\circ} \mathrm{C}$ with photoperiod regime of $14 \mathrm{~h}$ light/10 $\mathrm{h}$ dark and light intensity of approximately $400 \mu \mathrm{mol} \mathrm{m} \mathrm{sec}^{-1}$.

\section{Feminization of male plants by 6-benzylaminopurine treatment}

At the onset of flowering (about 25-day-old plants), male plants were separated from female plants. Feminization of the isolated male plants was done by spraying $1 \mathrm{mg} \mathrm{L}^{-1}$ 6benzylaminopurine (BAP) three times daily as described (Durand and Durand 1991; Khadka et al., 2005). Inflorescence bud samples were collected and either used immediately for nuclei isolation or stored at $-80^{\circ} \mathrm{C}$ until analyzed.

\section{Proteomic analysis}

Nuclei isolated from flower buds were subjected to proteome analysis by the proteomic services of The Smoler Protein Research Center at the Technion, Israel. The samples were digested by trypsin, analyzed by LC-MS/MS on Q-Exactive (Thermo) and identified by Discoverer1.4 software against Ricinus communis, Jatropha curcas and Arabidopsis protein databases. All the identified peptides were filtered with high confidence, top rank and mass accuracy. High confidence peptides were passed the $1 \%$ FDR threshold (FDR =false discovery rate, is the estimated fraction of false positives in a list of peptides). The peak area on the chromatogram of the protein was calculated from the average of the peptides from each protein. PANTHER classification tool was used for categorization of differentially expressed proteins (Mi et al., 2013).

\section{Nucleic acid extraction and cDNA synthesis}

Genomic DNA was extracted using the PureLink Genomic DNA Mini Kit according to the manufacturer's protocol (ThermoFisher Scientific). Total RNA was extracted using the 
156 RNeasy Mini Kit (Qiagen). The first strand of cDNA was synthesized from $1 \mu \mathrm{g}$ DNase

157 (Epicentre)-treated total RNA using Verso cDNA Synthesis Kit (ThermoFisher Scientific).

\section{Isolation of genes and partial promoter sequences}

159 Floral homeotic cDNA clones were prepared by PCR using $M$. аппиа flower cDNA as 160 template and appropriate degenerate primers (based on conserved regions of A. thaliana, 161 Ricinus communis and Jatropha curcas; for primer sequences see Supplementary file 1) for 162 the recovery of class B (AP3, PI, TM6), class C/D (AG, AGL5 and AGL11), as well as two 163 SUPERMAN-like (SUP-like) gene products. PCR conditions were: $95^{\circ} \mathrm{C}, 2 \mathrm{~min}$; 40 cycles of $16495{ }^{\circ} \mathrm{C}, 30 \mathrm{~s} ; 65-45^{\circ} \mathrm{C}, 30 \mathrm{~s} ; 72{ }^{\circ} \mathrm{C}, 60 \mathrm{~s}$; followed by $72{ }^{\circ} \mathrm{C}, 5 \mathrm{~min}$. The PCR products were 165 purified using QIAquick gel extraction kit, then cloned into pJET1.2 plasmid vector 166 (ThermoFisher scientific) and sequenced at the Biotechnology Center, Ben-Gurion University 167 of the Negev, Beer-Sheva, Israel.

168 169

To obtain full cDNA sequence, 3'- RACE was performed as described by Yadav et al. (2012) and 5'-RACE was performed using a 5'-Full RACE Core Set kit (TaKaRa). The purified PCR products were directly sequenced as above.

Based on phylogenetic analyses (see supplementary text for details), the class B genes were designated as MaPI for PI ortholog, MaAP3 for AP3 ortholog, MaTM6 for TOMATO MADS BOX GENE6 ortholog. The AGAMOUS-like genes were designated as MaAGl for AGAMOUS ortholog (class C), MaAGL1 for STK/AGL11 ortholog (class D) and MaAGL3 for SHP2/AGL5 ortholog (class D). NCBI GenBank accession numbers: KR781112-6.

The upstream promoters of MaAP3, MaAGL1, MaPI, MaSL1 and MaSL2 were isolated by semi-random sequence walking strategy modified from Aquino and Figueiredo (2004). Briefly, a gene specific primer was used for linear amplification of specific DNA segment for 20 high stringency cycles $\left(95{ }^{\circ} \mathrm{C}, 30 \mathrm{~s} ; 60{ }^{\circ} \mathrm{C}, 30 \mathrm{~s} ; 72{ }^{\circ} \mathrm{C}, 2 \mathrm{~min}\right)$. Then random walking primer was added and a low stringency cycle $\left(95{ }^{\circ} \mathrm{C} 30 \mathrm{~s}, 35{ }^{\circ} \mathrm{C} 30 \mathrm{~s}, 72{ }^{\circ} \mathrm{C} 2 \mathrm{~min}\right.$ ) was used for unspecific binding and amplification. Then, 30 high stringency cycles were used for exponential amplification. The desired fragments were screened by semi-nested PCR using asymmetrical ratio (1:5) of walking primer and nested gene specific primer. The products of interest were purified, cloned and sequenced as above. 
185

186

187

188

189

190

191

192

193

194

195

196

197

198

199

200

201

202

203

204

205

206

207

208

209

210

211

For reference, a $135 \mathrm{bp}$ of Actin gene was amplified using primers designed from conserved region of mRNA of $J$. curcas, $R$. communis and Populus trichocarpa. The amplified product of M. annua ACTIN (Act) gene was confirmed by direct sequencing from both ends.

\section{Gene expression analysis}

Quantification of the gene expression level was done by quantitative or semi-quantitative RTPCR analysis using gene specific primers. qPCR was carried out using Perfecta SYBR green supermix (Quanta Biosciences). Amplification was conducted on an Applied Biosystems ${ }^{\circledR}$ 7500 Real-Time PCR Systems. All reactions were performed from three biological samples and each with three technical replicates. The PCR conditions were: $94{ }^{\circ} \mathrm{C}$ for $15 \mathrm{~s}, 40$ cycles of $94{ }^{\circ} \mathrm{C}$ for $5 \mathrm{~s}, 60{ }^{\circ} \mathrm{C}$ for $30 \mathrm{~s}$. Each reaction was normalized against the expression of Actin gene. The relative changes in gene expression was calculated using the $2^{-\Delta \Delta C T}$ method (Livak and Schmittgen, 2001).

\section{Micrococcal nuclease accessibility assay}

Micrococcal nuclease (MNase) accessibility assay was performed as described (Zhao et al., 2001). Nuclei prepared from male and feminized $M$. аппиа flower buds were incubated with MNase for various durations, and the DNA was resolved on agarose gel. MNase treatment resulted in a nucleosomal ladder. The recovery of DNA after MNase treatment was checked by PCR.

\section{DNA methylation analysis}

For cytosine methylation analysis, chop-PCR (methylation-sensitive enzyme digestion followed by PCR) and bisulfite sequencing were performed as described (Yadav et al., 2018). In chop-PCR, genomic DNA was treated with methylation sensitive restriction enzymes HpaII or MspI and subjected to PCR to amplify various gene fragments containing the restriction site 'CCGG'.

Bisulfite conversion was done by adding a mixture of sodium bisulfite, hydroquinone and urea, and incubated at $55{ }^{\circ} \mathrm{C}$ for $16 \mathrm{hrs}$. The samples were desalted using PCR purification kit and desulfonated by adding $\mathrm{NaOH}$ to a final concentration of $0.3 \mathrm{M}$. Then, DNA was purified 
212 by QIAquick PCR purification kit (Qiagen). The bisulfite converted DNA was used for PCR

213 amplification of promoter and gene-body of MaAP3 and MaSL1 genes. The PCR products

214 were cloned into pJET1.2 vector. At least 10 individual clones from each region were

215 sequenced by Macrogen, Netherlands. The sequences were analyzed and scored using

216 Kismeth online service (Gruntman et al. 2008).

\section{Statistical analysis}

218 The data representing the average values of three biological replicates each with three

219 technical chemical replicates and error bars representing the standard deviations were

220 graphed. Student's t-test was used to determine the statistical significance of differences at the

221 p-level of 0.01. Error bars indicate SE of the mean $(n=3)$.

222 


\section{Results}

\section{Feminization of male Mercurialis annua: setting up the experimental system}

225

226

The female and male M. апnиa plants have distinct inflorescence morphology (Fig. 1A and 1B). In female plants, flowers developed directly at leaf axils with short pedicels, while in male plants, clusters of flowers developed on long pedunculated inflorescences. Feminization of male flowers by the cytokinin, 6-Benzylaminopurine (BAP), caused development of female flowers that yielded fertile seeds (Fig. 1C) on male inflorescences (Khadka et al., 2005).

\section{Proteome analysis of flower bud nuclei}

To identify regulatory genes involved in sexual dimorphism and BAP induced sex alteration of M. аппиа, we performed proteome analysis of nuclear proteins derived from flower buds of female, male and males treated with BAP for 4, 8, 12 and 16 days. The proteome data showed a total of 1443 proteins. Nuclear proteins including core histone proteins H2A, H2B, H3 and $\mathrm{H} 4$ displayed the highest intensities among the proteins identified in this analysis (Supplementary file 2, S1). The major difference between the genders was that 52 proteins that were present in female flowers were absent in male flowers, while 244 proteins that were present in males were absent in female flowers. Among the 52 proteins expressed only in female flowers, 49 proteins were up-regulated in feminized males (Supplementary file 2, S2). Out of the 244 male-specific proteins, 84 proteins were disappeared in the course of feminization (Supplementary file 2, S3). The change in protein expression was as follows: 39 proteins disappeared after 4 days of BAP treatment, 15 after 8 days, 12 after 12 days and 18 proteins disappeared after 16 days of BAP treatment.

Multiple classes of proteins were identified by categorization analysis of the differentially expressed proteins in feminized male. The major up-regulated protein classes were nucleic acid binding proteins, transcription factors and cytoskeleton proteins (Fig. 2A), and the major down-regulated protein classes were hydrolases, nucleic acid binding proteins, ligases and transferases (Fig. 2B). Among differentially expressed proteins, four floral organ identity MADS-box transcription factors were identified. The class E proteins, SEPALLATA1 (SEP1) and SEPALLATA3 (SEP3), and the class D protein SHP2/AGL5 were up-regulated during feminization, reaching a maximum at day 16 (Fig. 2C, D and E). In contrast, the class B 
252 protein PISTILLATA $(P I)$ was down-regulated within 4 days and disappeared completely 253 afterwards (Fig. 2F).

\section{Differential expression of floral homeotic genes}

255 The proteome data prompted cloning and analysis of $M$. апnиa orthologs of floral homeotic 256 MADS-box genes. The RNA expression pattern of the isolated genes in female and male 257 flowers, at bud and opened-flower stages was investigated (Fig.3). The class B genes MaPI 258 and MaAP3 were highly expressed in male flowers and poorly expressed in female flowers

259 (Fig. 3A and 3B). The class C gene, MaAGl was strongly expressed with similar level in 260 female and male flowers (Fig. 3C). In contrast, the class D genes MaAGL1 and MaAGL3 were 261 strongly expressed in female flowers and poorly expressed in male flowers (Fig. 3D and 3E). 262 Moreover, the expression level of most floral genes was significantly different $(\mathrm{p}<0.01)$ 263 between the floral bud stage and the open flower stage; the expression of MaAP3 and MaAG1 264 was higher at flower bud developmental stage, while the expression of MaPI and MaAGL3 265 was higher at open flower developmental stage (Fig. 3A, B, C and E).

266

267

268

269

270

271

272

273

274

275

276

277

278

279

280

The flower organ specificity of gene expression (Fig. 4) showed that MaPI and MaAP3 were almost exclusively expressed in male flowers, noteworthy that MaPI was also strongly expressed in peduncles. MaTM6 gene expression was evident in flowers of female and male plants. The MaTM6 expression was relatively higher in flowers and low in vegetative organs of female plants. In the male, MaTM6 expression was highest in flowers, moderate in leaves and peduncles, and very low in stem and roots. MaAGL1 and MaSL1 were exclusively expressed in flowers of female plants. MaAGl was expressed at moderate level in flowers of both sexes, and at lower level in peduncle of male plants. MaAGL3 was highly expressed in flowers of female and slightly lower expression in flowers and peduncles of male plants.

BAP-induced feminization of male plants resulted in changes in expression patterns of floral genes (Fig. 5). The expression of the class B identity gene MaTM6 was not significantly affected by feminization, while $M a P I$ and $M a A P 3$ were down-regulated. In contrast, the expression of class C/D floral genes, namely, MaAG1, MaAGL1 and MaAGL3 as well as MaSL1 was up-regulated by feminization. A significant up-regulation of class $\mathrm{C}$ and $\mathrm{D}$ genes was observed at 8-11 days of BAP treatment. 


\section{Epigenetic regulation of floral genes}

282

283

284

285

286

287

288

289

290

291

292

293

294

295

296

297

298

299

300

301

302

303

304

305

306

307

308

309

310

311

312

Epigenetics has often been implicated in sex determination in dioecious plants (Janousek et al., 1996; Brautigam et al., 2017). We thus wanted to address the involvement of epigenetic mechanisms in the regulation of floral gene expression. To this end, we first examined the chromatin configuration of promoters of several floral genes by micrococcal nuclease (MNase) assay. The MNase-treated nuclei from male and feminized male flowers (after 14 days of BAP treatment) showed similar progressive digestion of genomic DNA with notable nucleosomal ladders (Fig. 6A). MNase-digested DNAs was used as templates for PCR analysis of promoter regions of several genes. The results showed (Fig. 6B) two major digestion pattern reflecting open and relatively close chromatin configuration. Yet no notable differences in digestion pattern could be observed between male and feminized male flowers. Accordingly, group I consists the promoter regions of class $\mathrm{B}$ genes MaPI and MaAP3 showing higher sensitivity to MNase digestion similarly to actin, a constitutively expressed gene. Group II, which composed of the class D gene MaAGL1 as well as MaSL1 and MaSL2 were more resistant to MNase digestion (Fig. 6B). Thus, it appears that class B genes that assume an open chromatin conformation in male flowers remained open upon feminization, while class D assumes a relatively close configuration in male and feminized male flowers.

To examine the role of DNA methylation in the control of chromatin configuration and expression of floral genes, the status of cytosine methylation at the promoter regions of several differentially expressed genes, namely, MaSL1, MaSL2 and MaAGL1 was assayed by chop-PCR using the methylation sensitive enzymes HpaII and MspI. Notably, both enzymes recognize the CCGG site but differ in their sensitivity to cytosine methylation. While HpaII is sensitive when either of cytosine is methylated, MspI is sensitive only when the external cytosine is methylated, allowing distinguishing between CG and CHG methylation. ChopPCR revealed no differences in $\mathrm{CpG}$ methylation status of the examined genes in female and male flowers. However, CHG methylation appeared to be absent from the promoter regions of MaAGL1 and MaSL2 genes in male flowers inasmuch as no recovery of PCR fragment could be detected from $M s p$ I digest (Fig. 7A). We also perform bisulfite sequencing of MaAP3 and MaSL1 promoter and gene body regions showing no differences in DNA methylation status between male and female flowers. The promoter regions of both genes were highly methylated at all cytosine contexts $(\mathrm{CG}, \mathrm{CHG}$ and $\mathrm{CHH})$ while their gene bodies were essentially unmethylated (Fig. 7B). 


\section{Discussion}

314 The annual dioecious Mercurialis annua is a unique experimental system to study 315 mechanisms underlying plant sexual dimorphism. A major advantage of this species is the 316 possibility to feminize male plants that produce viable seeds. The change of the fate of the 317 male flower development by cytokinin treatment of the plants (Louis et al., 1990; Duran and 318 Durand, 1991), enabled investigation of gene regulation at various levels: proteome, mRNA 319 and epigenetics. The data obtained in this study regarding the expression of floral identity 320 genes are consistent with their known function in determining sexual identity of floral organs 321 in various plant species. It has been shown previously that class B genes were highly 322 expressed in male flowers, of the type-II dioecious plants Thalictrum dioicum and Spinacia 323 oleracea (Di Stilio et al., 2005; Pfent et al., 2005). In agreement, our results showed that male 324 flowers are characterized by a strong expression of class B genes, MaPI and MaAP3, 325 concomitantly with suppression of female identity genes such as MaAGL1 (class D) and 326 MaSL1. The involvement of cytokinin in sex determination has been reported in a variety of 327 plant species including the oilseed crops Plukenetia volubilis and Jatropha curcas (Pan and $328 \mathrm{Xu}, 2011 ; \mathrm{Fu}$ et al., 2014).

\section{Expression pattern of floral genes}

330 Proteome analysis of BAP feminized males showed differential expression of several protein 331 families including nucleic acid binding proteins, hydrolases, ligases, transferases and 332 transcription factors. Interestingly, floral homeotic MADS-box gene product homologs of 333 Arabidopsis class E genes, SEP1, SEP3 and class D gene SHP2/AGL5 were up-regulated and 334 homolog of class B gene, PI, involved in specification of petals and stamens, was downregulated in feminized males. The proteins, SEP1 and SEP3 were implicated in regulation of all four flower whorls of Arabidopsis (Zahn et al., 2005); while in other plants species, SEPlike genes play diverse roles in growth and development including plant architecture, ovule development, fruit ripening, inflorescence architecture and reproductive meristem fate (Uimari et al. 2004; Biewers, 2014). In Gerbera hybrida two duplicated orthologs of SEP-like gene GRCD1 and GRCD2 were sub-functionalized for stamen and carpel identity,

341 respectively. The Mercurialis orthologs of SEP1 and SEP3 proteins presented here might have a role in female flower specification. The up-regulation of SHP2/AGL5 in feminized 
344 constitutive expression of SHP genes in Arabidopsis resulted in a partial conversion of the 345 first whorl sepals into carpel-like structures demonstrated by extensive proliferation of 346 stigmatic papillae (Favaro et al., 2003; Pinyopich et al., 2003). The PI protein, which was down-regulated in feminized males was involved in controlling the development of whorls 2 and 3 in Arabidopsis, Antirhinum and tomato (Trobner et al., 1992; Goto and Mayerowitz, 1994; Guo et al., 2016). Thus, these results suggest that the cytokinin switched-off the male control genes (e.g., PISTILLATA) concomitantly with up-regulation of female identity genes consequently leading to the replacement of stamen by carpels, as in the development of normal dioecious female flower.

An earlier study, using a cell-free translation system with RNAs derived from M. аппиа male and female flowers demonstrated peptide variation between the two sexes and that cytokinininduced feminization of male flowers has led to the expression of female-specific peptides (Deligue et al., 1984). Similarly, we found that cytokinin-induced feminization of M. апnиa male flowers was associated with upregulation of female-specific floral genes concomitantly with downregulation of male-specific genes. The effect of cytokinin on floral gene expression was reported previously (Estruch et al., 1993). Accordingly, the expression of the cytokininsynthesizing gene IPT in transgenic tobacco plants resulted in abnormal flower development concomitantly with a notable decrease in accumulation of class B genes (DEFA, GLO) and class C gene (PLENA) (Estruch et al., 1993). In Arabidopsis, exogenous application of BAP was reported to promote differentiation of carpeloid tissue and suppress stamen development. This is similar to the effect obtained by overexpressing SUP in tobacco plants leading to the proposition that SUP may regulate sex determination pathways by promoting female organ differentiation via its effect on cytokinin signaling (Nibau et al., 2011). Alternatively, cytokinin may affect male and female flower development via controlling SUP expression. Indeed, in M. апnиa as well as in the dioecious Popolus tomentosa and Silene latifolia the SUP-like genes exhibited female flower-specific expression (Kazama et al., 2009; Song et al., 2013). In Arabidopsis, sup mutant was associated with the ectopic expression of AP3 gene in the fourth whorl (Bowman et al., 1992), therefore SUP was proposed to function as a negative regulator of $A P 3$. The concomitant expression of class B and SUP-like genes in male flower buds suggests that $S U P$-like gene(s) might not be a transcriptional regulator of class B genes in $M$. аппиа. An alternative possibility is that the $S U P$ gene expression in male flower buds is negatively regulated post-transcriptionally. 
The expression of class B gene, MaAP3, was restricted to male flowers, while MaTM6 (AP3-related) and MaPI, were expressed in flowers as well as in peduncles (Fig. 4). It is noteworthy that TM6, which is absent in A. thaliana, was also expressed in leaves of $M$. апnиа male plants and weakly in other vegetative organs. The broader expression pattern of TM6 orthologs was reported in Carica papaya (CpTM6-2) and Vitis vinifera (VvTM6); CpTM6-2 was expressed at a low level in sepals and at a high level in leaves (Ackerman et al., 2008), while VvTM6 was expressed throughout the plant, though displaying high levels in flowers and berries (Poupin et al., 2007). It has been proposed that a gene duplication event of the paleoAP3 genes resulted in two types, euAP3 and TM6 lineages that are distinguished by their C-terminal regions (Kramer et al., 1998). These duplicated genes probably adopted, to some extent, different functions (sub-functionalization) demonstrated by their tissue-specific patterns of expression and the effect of their loss-of-function on flower development (Eckardt, 2006).

The expression of class $\mathrm{C}$ gene, MaAGl was similar in male and female flowers of $M$. annua suggesting it may not involve in gender determination. This is consistent with previous reports showing that the $\mathrm{C}$ class $A G$ genes are involved in the floral quartet specifying both stamens and carpels (reviewed in Theissen et al., 2016). The class D genes, MaAGL1 and MaAGL3 were highly expressed in female flowers; MaAGL3 was also expressed in male flowers as well as in peduncles (Fig. 4). Our results suggest that class B genes MaAP3, MaPI together with class $\mathrm{C} \mathrm{MaAGl}$ have a role in determining the identity of male floral organs. These gene products may participate in the floral quartet that controls gene expression and male reproductive organ identity (Theissen et al., 2016). On the other hand, class D genes MaAGL1 and MaAGL3 together with class $\mathrm{C}$ and class $\mathrm{E}$ genes may form a floral quartet that specifies female floral organs, carpels and ovules. Notably, in seed plants the class B genes have been suggested to have a primary role in sex-determination (Winter et al., 1999). Accordingly, expression of both, class B and class $\mathrm{C}$ genes specify male reproductive organs while the expression of only class $\mathrm{C}$ genes specify female reproductive organs. Thus, switching from male to female and vice versa can be solely driven by changes in the spatiotemporal expression of class B genes (Winter et al., 1999; Theissen and Melzer, 2007). Our data however showed that induction of feminization was associated not only with turning off expression of class $B$ genes but also with up-regulation of class $C / D$ genes, which might be crucial for the development of female flower in otherwise male plants of M. апnиa. 
Our data showed that there is no clear relationship between floral homeotic genes and their epigenetic makeup (Table 1). Gene expression is primarily regulated at the chromatin level where gene transcription requires open chromatin to allow for the transcription machinery to approach the gene locus. The analysis of chromatin accessibility by MNase assay revealed that in male flowers class B genes MaPI and MaAP3 assume an open chromatin conformation similar to the constitutively expressed gene Actin. On the other hand, class D genes MaAGL1 and SUP-like genes MaSL1 and MaSL2 appeared to acquire a relatively close conformation, which is consistent with the lack of expression in male flowers. Surprisingly, however, upon feminization and up-regulation of MaAGL1 and MaSL1 no apparent change in accessibility of chromatin to MNase was evident. This suggests that chromatin can assume different levels of open chromatin conformation that provide another regulatory layer for control of gene expression (Ishihara et al., 2010; Kotomura et al., 2015). Similarly, no change in chromatin accessibility was observed for the down-regulated class B genes, $M a P I$ and $M a A P 3$, whose transcription was possibly halted in an open chromatin environment by other means (e.g., suppressor proteins).

The nature of gene regulation by DNA methylation is not fully understood, but generally DNA methylation has been implicated in regulating chromatin structure and function (Niederhuth and Schmitz, 2017). DNA methylation was detected at promoters but not at gene-bodies of the examined floral genes. Interestingly, methylation status of all tested genes was similar in both sexes despite of their differential expression. In Arabidopsis, gene methylation was reported to correlate with gene expression level; gene-body methylation was correlated with constitutively and highly expressed genes, while promoter methylation was correlated with weakly expressed genes, which are usually tissue-specific (Zhang et al., 2006; Zilberman et al., 2007). However, in this work, a consistent correlation between DNA methylation and expression of the floral genes in M. аппиа was not found (Table 1 and Fig. 7). The floral genes MaAP3, MaAGL1, MaSL1 and MaSL2 were normally transcribed in spite of being heavily methylated at their promoters. Thus, it appears that DNA methylation at promoter regions of $M$. аппиа floral genes had a positive effect on floral gene expression, in contrast to the commonly known effect of suppression of expression by methylation, particularly when transposable elements are concerned (Lisch, 2009). This finding can plausibly be explained by lowering the affinity of repressors to their binding sites by DNA 
440 methylation. There are indeed reports that showed likewise that DNA methylation at 441 promoters contributes to transcriptional activation of certain tissue-specific genes (Neissen et 442 al., 2005; Weber et al., 2007; Rishi et al., 2010; Bahar Halpren et al., 2014).

443 We concluded that determination of sex organ identity in $M$. annua does not primarily 444 involve epigenetic regulation of floral homeotic genes. Rather, the gender identity of a 445 dioecious flower seems to be controlled up-stream in the regulatory pathway by a gender446 specific regulator(s) that affects hormonal homeostasis. This is further supported by a recent 447 report that identified only a handful number of epigenetically-regulated genes within the sex448 determining region of Populus balsamifera (Brautigam et al., 2017). In that work it was 449 shown that both the promoter and gene body of PbRR9 were methylated. Since this gene is a 450 member of the two-component response regulator (type-A) gene family, which is involved in 451 cytokinin signaling, it would be important to explore further the role of genes involved in 452 hormonal homeostasis in sex determination in M. annua. 


\section{Supplementary data}

455 Supplementary file 1

456 Text: Sequence and phylogenetic analysis of floral MADS-box and SUPERMAN-like genes

457 Fig. S1. Phylogenetic analysis of class B genes from M. апnиa, A. thaliana and various 458 taxonomic groups.

459 Fig S2: Phylogenetic analysis of $A G$-like genes from M. annua, A. thaliana and various 460 taxonomic groups.

461 Fig S3: Phylogenetic analysis of SUPERMAN-like genes from M. anпиa, A. thaliana and 462 various taxonomic groups.

463 Table S1: List of primers used in this study

464 Supplementary file 2 (Excel Sheets)

465 S1: List of proteins identified in proteomic analysis

466 S2: Proteins exclusively present in female flower buds that appeared following BAP treatment

467 S3: Proteins exclusively present in male flower buds that disappeared following BAP 468 treatment

\section{Acknowledgements}

470 We acknowledge the support of the Albert Katz International School for Desert Studies for 471 the graduate scholarship of JK. Also, The Blaustein Center for Scientific Cooperation (BCSC) 472 and the PBC Program of Israeli Council for Higher Education for post-doctoral fellowships to 473 NSY. This project was supported by the Frances and Elias Margolin Trust and by ICA in 474 Israel, as well as by The Hans-Fischer-Gesellschaft, Munich and BAYHOST funding 475 provided by the Bayerisches Staatsministerium für Bildung und Kultur, Wissenschaft und 476 Kunst. 


\section{References}

Ackerman CM, Yu Q, Kim S, Paull RE, Moore PH, Ming R. 2008. B-class MADS-box genes in trioecious papaya: two paleoAP3 paralogs, CpTM6-1 and CpTM6-2, and a PI ortholog CpPI. Planta 227, 741-753.

Ainsworth C, Crossley S, Buchanan-Wollaston V, Thangavelu M, Parker J. 1995. Male and Female Flowers of the Dioecious Plant Sorrel Show Different Patterns of MADS Box Gene Expression. The Plant Cell 7, 1583-1598.

Aquino VH, Figueiredo LTM. 2004. Linear amplification followed by single primer polymerase chain reaction to amplify unknown DNA fragments: Complete nucleotide sequence of Oropouche virus M RNA segment. Journal of Virological Methods 115, 5157.

Bahar Halpern K, Vana T, Walker MD. 2014. Paradoxical role of DNA methylation in activation of FoxA2 gene expression during endoderm development. The Journal of Biological Chemistry 289, 23882-23892.

Biewers SM. 2014. Sepallata genes and their role during floral organ formation. PhD thesis, University of Leeds.

Bowman JL, Sakai H, Jack T, Weigel D, Mayer U, Meyerowttz EM. 1992. SUPERMAN, a regulator of floral homeotic genes in Arabidopsis. Development 114, 599-615.

Brautigam K, Soolanayakanahally R, Champigny M, Mansfield S, Douglas C, Campbell MM, Cronk Q. 2017. Sexual epigenetics: gender-specific methylation of a gene in the sex determining region of Populus balsamifera. Scientific Reports 7, 1-8.

Charlesworth B, Charlesworth D. (1978). A model for the evolution of dioecy and gynodioecy. The American Naturalist 112, 975-997.

Charlesworth D. 2002. Plant sex determination and sex chromosomes. Heredity 88, 94-101.

Coen ES, Meyerowitz EM. 1991. The war of the whorls: genetic interactions controlling flower development. Nature 353, 31-37.

Davies B, Egea-cortines M, Silva EDA, Saedler H, Sommer H. 1996. Multiple interactions amongst floral homeotic MADS box proteins. The EMBO Journal 15, 4330-4343.

Delaigue M, Poulain T, Durand B. 1984. Phytohormone control of translatable RNA populations in sexual organogenesis of the dioecious plant Mercurialis annua L. $(2 \mathrm{n}=$ 16). Plant Molecular Biology 3, 419-429.

Di Stilio VS, Kramer EM, Baum DA. 2005. Floral MADS box genes and homeotic gender dimorphism in Thalictrum dioicum (Ranunculaceae) - a new model for the study of dioecy. Plant Journal 41, 755-766.

Durand B, Durand R. 1991. Sex determination and reproductive organ differentiation in Mercurialis. Plant Science 80, 49-65. 
Eckardt NA. 2006. Functional divergence of AP3 genes in the MAD world of flower development. The Plant Cell 18,1779-1781

Estruch JJ, Granell A, Hansen G, Prinsen E, Redig P, Van Onckelen H, SchwarzSommer Z, Sommer H, Spena A. 1993. Floral development and expression of floral homeotic genes are influenced by cytokinins. Plant Journal 4, 379-384.

Favaro R, Pinyopich A, Battaglia R, Kooiker, M, Borghi L, Ditta G, Yanofsky MF, Kater MM, Colombo L. 2003. MADS-box protein complexes control carpel and ovule development in Arabidopsis. The Plant Cell 15, 2603-2611.

Fu QT, Niu LJ, Zhang QF, Pan BZ, He HY, Xu ZF. 2014. Benzyladenine treatment promotes floral feminization and fruiting in a promising oilseed crop Plukenetia volubilis. Industrial Crops and Products 59, 295-298.

Gaiser JC, Robinson-Beers K, Gasser CS. 1995. The Arabidopsis SUPERMAN Gene Mediates Asymmetric Growth of the Outer Integument of Ovules. Plant Cell 7, 333-345.

Goto K, Meyerowitz EM. (1994). Function and regulation of the Arabidopsis floral homeotic gene PISTILLATA. Genes and Development 8, 1548-1560.

Gruntman E, Qi Y, Slotkin RK, Roeder T, Martienssen RA, Sachidanandam R. 2008. Kismeth: Analyzer of plant methylation states through bisulfite sequencing. BMC Bioinformatics 9, 1-8.

Hardenack S, Ye D, Saedler H, Grant S. 1994. Comparison of MADS box gene expression in developing male and female flowers of the dioecious plant white campion. The Plant Cell 6, 1775-1787.

Jack T, Brockman LL, Meyerowitz EM. 1992. The homeotic gene apetala 3 of Arabidopsis thaliana encodes a MADS box and is expressed in petals and stamens. Cell 68, 683-697.

Jacobsen SE, Meyerowitz EM. 1997. Hypermethylated SUPERMAN Epigenetic Alleles in Arabidopsis. Science 277, 1100-1103.

Janousek B, Siroký J, Vyskot B. 1996. Epigenetic control of sexual phenotype in a dioecious plant, Melandrium album. Molecular and General Genetics 250, 483-490.

Ishihara S, Varma R, Schwartz RH. 2010. A new fractionation assay, based on the size of formaldehyde-crosslinked, mildly sheared chromatin, delineates the chromatin structure at promoter regions. Nucleic acids research 38, 1-10.

Kazama Y, Fujiwara MT, Koizumi A, Nishihara K, Nishiyama R, Kifune E, Abe T, Kawano S. 2009. A SUPERMAN-like gene is exclusively expressed in female flowers of the dioecious plant Silene latifolia. Plant Cell Physiology 50, 1127-1141.

Khadka DK, Nejidat A, Tal M, Golan-Goldhirsh A. 2005. Molecular characterization of a gender-linked DNA marker and a related gene in Mercurialis annua L. Planta 222, 1063-1070. 
Khadka DK, Nejidat A, Tal M, Golan-Goldhirsh A. 2002. DNA markers for sex: Molecular evidence for gender dimorphism in dioecious Mercurialis annua L. Molecular Breeding 9, 251-257.

Kotomura N, Harada N, Ishihara S. 2015. The Proportion of Chromatin Graded between Closed and Open States Determines the Level of Transcripts Derived from Distinct Promoters in the CYP19 Gene. PloS one 10, 1-20.

Kramer EM, Dorit RL, Irish VF. 1998. Molecular evolution of genes controlling petal and stamen development: duplication and divergence within the APETALA3 and PISTILLATA MADS-box gene lineages. Genetics 149, 765-783.

Krizek BA, Fletcher JC. 2005. Molecular mechanisms of flower development: an armchair guide. Nature Reviews Genetics 6, 688-698.

Lisch D. 2009. Epigenetic regulation of transposable elements in plants. Annual Review Plant Biology 60, 43-66.

Livak KJ, Schmittgen TD. 2001. Analysis of relative gene expression data using real-time quantitative PCR and the 2(-Delta Delta C(T)) Method. Methods 25, 402-408.

Louis JP, Augur C, Teller G. 1990. Cytokinins and Differentiation Processes in Mercurialis annua Genetic Regulation, Relations with Auxins, Indoleacetic Acid Oxidases, and Sexual Expression Patterns. Plant physiology 94, 1535-1541.

Mendes MA, Guerra RF, Berns MC, Manzo C, Masiero S, Finzi L, Kater MM, Colombo L. 2013. MADS Domain Transcription Factors Mediate Short-Range DNA Looping That Is Essential for Target Gene Expression in Arabidopsis. The Plant Cell 25, 2560 2572.

Mi H, Muruganujan A, Casagrande JT, Thomas PD. 2013. Large-scale gene function analysis with the PANTHER classification system. Nature protocols 8, 1551-1566.

Mitchell CH, Diggle PK. 2005. The evolution of unisexual flowers: Morphological and functional convergence results from diverse developmental transitions. American Journal of Botany 92, 1068-1076.

Nandi AK, Kushalappa K, Prasad K, Vijayraghavan U. 2000. A conserved function for Arabidopsis SUPERMAN in regulating floral-whorl cell proliferation in rice, a monocotyledonous plant. Current Biology 10, 215-218.

Nibau C, Di Stilio VS, Wu HM, Cheung AY. 2011. Arabidopsis and Tobacco SUPERMAN regulate hormone signalling and mediate cell proliferation and differentiation. Journal of Experimental Botany 62, 949-961.

Niederhuth CE, Schmitz RJ. 2017. Putting DNA methylation in context: from genomes to gene expression in plants. Biochimca et Biophysca Acta 1860, 149-156.

Nurrish SJ, Treisman R. 1995. DNA binding specificity determinants in MADS-box transcription factors. Molecular and Cellular Biology 15, 4076-4085. 
Orlofsky ME, Kozhoridze G, Lyubenova L, Ostrozhenkova E, Barbro Winkler J, Schroeder P, Bacher A, Eisenreich W, Guy M, Golan-Goldhirsh A. 2016. Sexual dimorphism in the response of Mercurialis annua to stress. Metabolites 6, 1-17.

O’Maoileidigh DS, Wuest SE, Rae L, et al. 2013. Control of Reproductive Floral Organ Identity Specification in Arabidopsis by the C Function Regulator AGAMOUS. The Plant Cell 25, 2482-2503.

Pan BZ, Xu ZF. 2011. Benzyladenine treatment significantly increases the seed yield of the biofuel plant Jatropha curcas. Journal of Plant Growth Regulation 30, 166-174.

Pannell JR, Dorken ME, Pujol B, Berjano R. 2008. Gender Variation and Transitions between Sexual Systems in Mercurialis annua (Euphorbiaceae). International Journal of Plant Sciences 169, 129-139.

Pfent C, Pobursky KJ, Sather DN, Golenberg EM. 2005. Characterization of SpAPETALA3 and SpPISTILLATA, B class floral identity genes in Spinacia oleracea, and their relationship to sexual dimorphism. Development Genes and Evolution 215, $132-142$.

Pinyopich A, Ditta GS, Savidge B, Liljegren SJ, Baumann E, Wisman E, Yanofsky MF. 2003. Assessing the redundancy of MADS-box genes during carpel and ovule development. Nature 424, 85-88.

Poupin MJ, Federici F, Medina C, Matus JT, Timmermann T, Arce-Johnson P. 2007 Isolation of the three grape sub-lineages of B-class MADS-box TM6, PISTILLATA and APETALA3 genes which are differentially expressed during flower and fruit development. Gene 404, 10-24.

Prunet N, Yang W, Das P, Meyerowitz EM, Jack TP. 2017. SUPERMAN prevents class B gene expression and promotes stem cell termination in the fourth whorl of Arabidopsis thaliana flowers. Proceedings of the National Academy of Sciences 114, 7166-7171.

Renner SS, Ricklefs RE. 1995. Dioecy and its correlates in the flowering plants. American Journal of Botany 82, 596-606.

Riechmann JL, Krizek, BA, Meyerowitz EM. 1996. Dimerization specificity of Arabidopsis MADS domain homeotic proteins APETALA1, APETALA3, PISTILLATA, and AGAMOUS. Proceedings of the National Academy of Sciences 93, 4793-4798.

Rishi V, Bhattacharya P, Chatterjee R, Rozenberg J, Zhao J, Glass K, Fitzgerald P, Vinson C. 2010. CpG methylation of half-CRE sequences creates C/EBP $\alpha$ binding sites that activate some tissue-specific genes. Proceedings of the National Academy of Sciences 107, 20311-20316.

Russell JRW, Pannell JR. 2015. Sex determination in dioecious Mercurialis annua and its close diploid and polyploid relatives. Heredity 114, 262-271. 
Sakai H, Medrano LJ, Meyerowitz EM. 1995. Role of SUPERMAN in maintaining Arabidopsis floral whorl boundaries. Nature 378, 199-202.

Sather DN, Jovanovic M and Golenberg EM. 2010. Functional analysis of B and C class floral organ genes in spinach demonstrates their role in sexual dimorphism. BMC Plant Biology. 10, 1-14.

Smaczniak C, Immink RGH, Muiño JM, et al. 2012. Characterization of MADS-domain transcription factor complexes in Arabidopsis flower development. Proceedings of the National Academy of Sciences 109, 1560-1565.

Soltis DE, Chanderbali AS, Kim S, Buzgo M, Soltis PS. 2007. The ABC model and its applicability to basal angiosperms. Annals of Botany. 100, 155-163.

Song Y, Ma K, Ci D, Tian X, Zhang Z, Zhang D. 2013. The SUPERMAN gene family in Populus: Nucleotide diversity and gene expression in a dioecious plant. Plant Cell Report 32, 1277-1288.

Stewart D, Graciet E, Wellmer F. 2016. Molecular and regulatory mechanisms controlling floral organ development. FEBS Journal 283, 1823-1830.

Theissen G, Saedler H. 2001. Plant biology Floral quartets. Nature 409, 469-471.

Theissen G, Melzer R. 2007. Molecular mechanisms underlying origin and diversification of the angiosperm flower. Annals of Botany 100, 603-619.

Theissen G, Melzer R, Rümpler F. 2016. MADS-domain transcription factors and the floral quartet model of flower development: linking plant development and evolution. Development 143, 3259-3271.

Thomas R. 1958. Sexuality in diploid and hexaploid races of Mercurialis annua L. Annals of Botany 22, 55-72.

Trobner W, Ramirez L, Motte P, Hue I, Huijser P, Lonnig WE, Saedler H, Sommer H, Schwarz-Sommer Z. 1992. GLOBOSA: a homeotic gene which interacts with DEFICIENS in the control of Antirrhinum floral organogenesis. The EMBO Journal 11, 4693-4704.

Uimari A, Kotilainen M, Elomaa P, Yu D, Albert VA, Teeri TH. 2004. Integration of reproductive meristem fates by a SEPALLATA-like MADS-box gene. Proceedings of the National Academy of Sciences 101, 15817-15822.

Veltsos P, Cossard G, Beaudoing E, Beydon G, Savova BD, Roux C, C GonzálezMartínez S, R Pannell J. 2018. Size and Content of the Sex-Determining Region of the Y Chromosome in Dioecious Mercurialis annua, a Plant with Homomorphic Sex Chromosomes. Genes 9, 1-15.

Weber M, Hellmann I, Stadler MB, Ramos L, Pääbo S, Rebhan M, Schübeler D. 2007. Distribution, silencing potential and evolutionary impact of promoter DNA methylation in the human genome. Nature Genetics 39, 457-466. 
Winter KU, Becker A, Münster T, Kim JT, Saedler H, Theissen G. 1999. MADS-box genes reveal that gnetophytes are more closely related to conifers than to flowering plants. Proceedings of the National Academy of Sciences 96, 7342-7347.

Wuest SE, Maoileidigh DSO, Rae L, Kwasniewska K, Raganelli A, Hanczaryk K, Lohan AJ, Loftus B, Graciet E, Wellmer F. 2012. Molecular basis for the specification of floral organs by APETALA3 and PISTILLATA. Proceedings of the National Academy of Sciences 109, 13452-13457.

Yadav NS, Khadka J, Domb K, Zemach A, Grafi G. 2018. CMT3 and SUVH4/KYP silence the exonic Evelknievel retroelement to allow for reconstitution of CMT1 mRNA. Epigenetics and Chromatin, 11, 1-12.

Yadav NS, Shukla P, Jha A, Agarwal PK, Jha B. 2012. The SbSOS1 gene from the extreme halophyte Salicornia brachiata enhances $\mathrm{Na}+$ loading in xylem and confers salt tolerance in transgenic tobacco. BMC Plant Biology 12, 1-18.

Yun JY, Weigel D, Lee I. 2002. Ectopic expression of SUPERMAN suppresses development of petals and stamens. Plant Cell Physiology 43, 52-57.

Zahn LM, Kong H, Leebens-Mack JH, Kim S, Soltis PS, Landherr LL, Soltis DE, Depamphilis CW, Ma H. 2005. The evolution of the SEPALLATA subfamily of MADS-box genes: a preangiosperm origin with multiple duplications throughout angiosperm history. Genetics 169, 2209-2223.

Zhang X, Yazaki J, Sundaresan A, Cokus S, et al. 2006. Genome-wide High-Resolution Mapping and Functional Analysis of DNA Methylation in Arabidopsis. Cell 126, 11891201.

Zhao J, Morozova N, Williams L, Libs L, Avivi Y, Grafi G. 2001. Two phases of chromatin decondensation during dedifferentiation of plant cells: distinction between competence for cell fate switch and a commitment for S phase. Journal of Biological Chemistry 276, 22772-22778

Zilberman D, Gehring M, Tran RK, Ballinger T, Henikoff S. 2007. Genome-wide analysis of Arabidopsis thaliana DNA methylation uncovers an interdependence between methylation and transcription. Nature Genetics 39, 61-69. 


\section{Figure legends}

Figure 1. Morphological observation of dioecious M. annua. (A) Female plant. (B) Male inflorescence. (C) Feminized male inflorescence, BAP-hormone was sprayed 3 times daily for 4 weeks. Note that feminized male produced bi-carpellet flowers (some are indicated by arrows).

Figure 2. Proteome analysis of nuclei isolated from female, male and BAP treated male flower buds. Categorization analysis of down-regulated (A) and up-regulated (B) proteins following male feminization. The LFQ intensity of SEPALLATA1 (C), SEPALLATA3 (D), SHP2/AGAMOUS-like5 (E) and PISTILLATA (F) proteins in female, male and BAP treated males for 4, 8, 12 and 16 days, is shown. F, Female; M, Male; DABAP, Days after initiation of BAP treatment. Note that LFQ (labelfree quantification) intensity reflects the relative amounts of the proteins, which was calculated using peptide intensities normalized between the samples.

Figure 3. Expression of MADS-box genes in flower buds and open flowers of female and male plants of M. annua. Relative expression of (A) MaPI, (B) MaAP3, (C) MaAG1, (D) MaAGL1 and (E) MaAGL3 genes determined using RT-qPCR. Y-axis shows relative transcript level of genes normalization to Actin gene. The values are average of three biological replicates. Values denoted by different numbers of asterisks are significantly different (Students $t$-test, $\mathrm{P}<0.01$ ). Error bars indicate the standard error of the mean $(n=3)$.

Figure 4. Expression pattern of floral homeotic genes in different organs of female and male plants of M. annua. Expression of class B, C, D and SUPERMAN-like genes was determined using semi-quantitative PCR using cDNAs derived from RNA prepared from the indicated organs. Actin was used as ubiquitously expressed reference gene. M, molecular size markers in base pairs.

Figure 5. A time course of the expression of floral genes during BAP-induced feminization. 25day-old M. аnnиa plants were sprayed 3 times daily with water (control male) or with cytokinin (BAPtreated male). Newly emerging inflorescences were collected on the indicated days, RNA was prepared and subjected to cDNA synthesis. The expression of the indicated floral genes was determined by semi-quantitative PCR using cDNAs as templates. The class to which floral homeotic genes belong is indicated on the left. Actin was used as reference gene.

Figure 6. Analysis of chromatin configuration of selected floral genes by micrococcal nuclease assay. (A) Nuclei prepared from male and feminized male flower buds (BAP-treated for 14 days, before female flowers are visible) were treated with MNase for the indicated time periods. DNA was extracted from MNase-treated nuclei and resolved on $1.5 \%$ agarose gel. $\mathrm{M}$, molecular size marker in 
base pairs. (B) Assessment of chromatin configuration of promoters of the indicated genes was performed by PCR using DNA recovered from MNase-treated nuclei (shown in A). Group I refers to male-related identity genes and Group II to Female-related identity genes. Actin was used as reference for open chromatin configuration. M, molecular size markers in base pairs.

Figure 7. Transcriptionally active floral genes are methylated in both genders of M. annua. (A) Analysis of DNA methylation at promoters of MaAGL1, MaSL1 and MaSL2 genes by Chop-PCR. A fragmet of the MaSL1 gene lacking CCGG site was used as control. Left panel is a control of undigested DNA (Ud). H, HpaII; M, MspI; L, molecular size markers in base pairs. (B) Analysis of methylation at promoter and gene-body of MaAP3 and MaSL1 genes by bisulfite sequencing. The percentage of cytosine methylation for each fragment was determined from at least 10 different clones. 
Table 1: Summary of the expression level of floral genes in relation to their epigenetic constraints.

\begin{tabular}{|c|c|c|c|c|c|c|c|c|c|c|c|c|}
\hline \multirow[t]{2}{*}{ Gene name } & \multicolumn{3}{|c|}{ expression } & \multicolumn{3}{|c|}{ DNA methylation } & \multicolumn{3}{|c|}{ Sensitivity to Mnase } & \multicolumn{3}{|c|}{ Score } \\
\hline & Female & Male & F-male & Female & Male & F-male & Female & Male & F-male & Female & Male & F-male \\
\hline MaPI & - & ++ & - & & & & & high & high & $\mathrm{S}$ & $O E$ & OS \\
\hline MaAP3 & - & +++ & - & mALL & mALL & & & high & high & $\mathrm{m} \mathrm{S}$ & $\mathrm{OmE}$ & OS \\
\hline MaActin & +++ & +++ & +++ & & & & & high & high & $E$ & O $\mathrm{E}$ & $\mathrm{OE}$ \\
\hline MaAGL3 & +++ & + & +++ & & & & & & & $E$ & e & $E$ \\
\hline MaAGL1 & +++ & - & ++ & mALL & mCG & & & low & low & $m E$ & $\mathrm{PO} \mathrm{m} \mathrm{S}$ & PO E \\
\hline MaSL1 & ++ & - & ++ & mALL & mALL & & & low & low & $m E$ & $\mathrm{PO} \mathrm{m} \mathrm{S}$ & PO E \\
\hline MaSL2 & ++ & - & - & mALL & mCG & & & low & Iow & $m E$ & PO S & PO S \\
\hline MaAG1 & +++ & ++ & +++ & & & & & & & $E$ & $E$ & $E$ \\
\hline
\end{tabular}

-, no expression; +, low expression; ++/+++, high expression; mAll, methylated at all C context; mCG, methylated at the CG context only; S, silent; E, expressed; e, low expression; O, Open chromatin; PO, Partial open chromatin. 
Figure 1

A Female

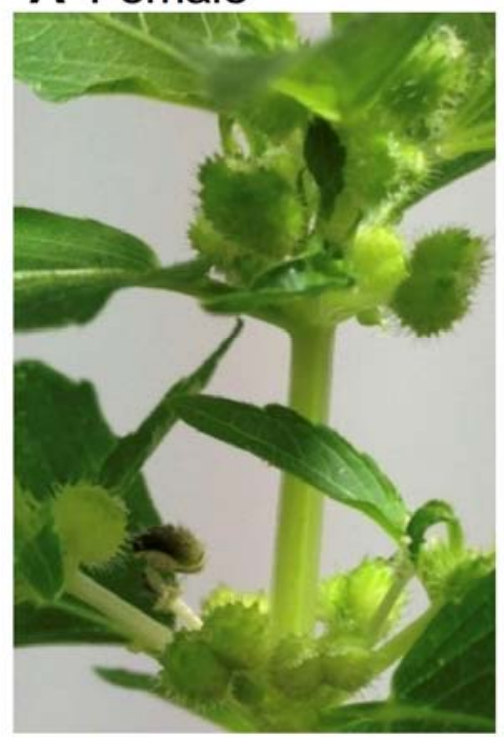

B Male

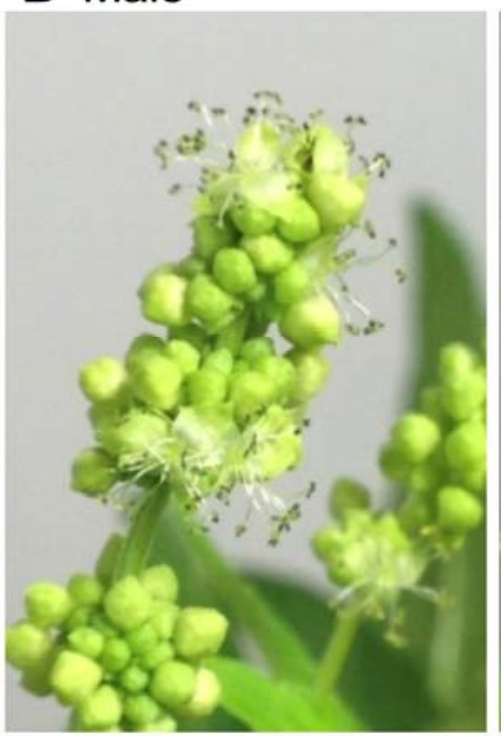

\section{Feminized male}

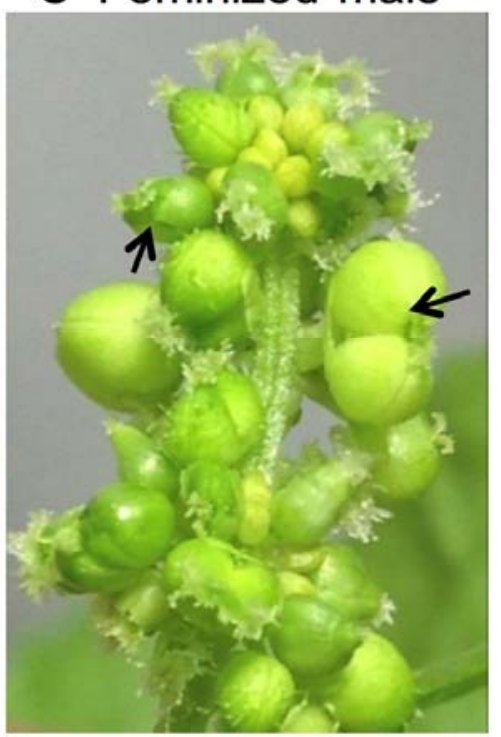


bioRxiv preprint doi: https://doi.org/10.1101/481481; this version posted November 29, 2018. The copyright holder for this preprint (which was not certified by peer review) is the author/funder. All rights reserved. No reuse allowed without permission.

Fig. 2

A

Up-regulated proteins in BAP treated male

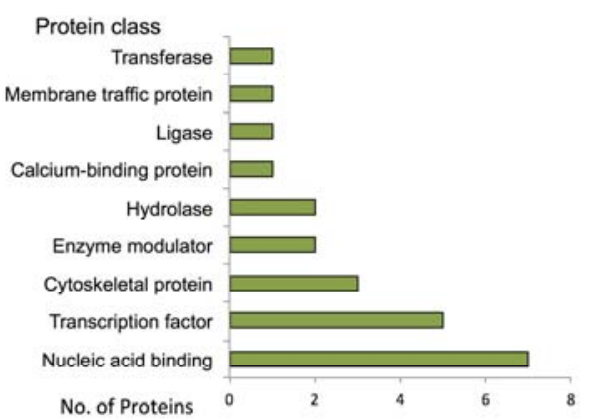

C

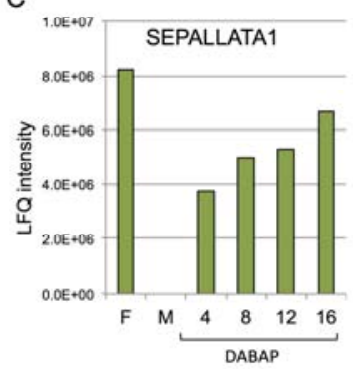

D

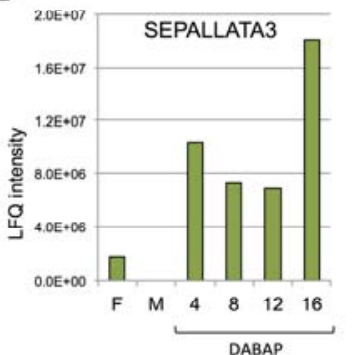

B

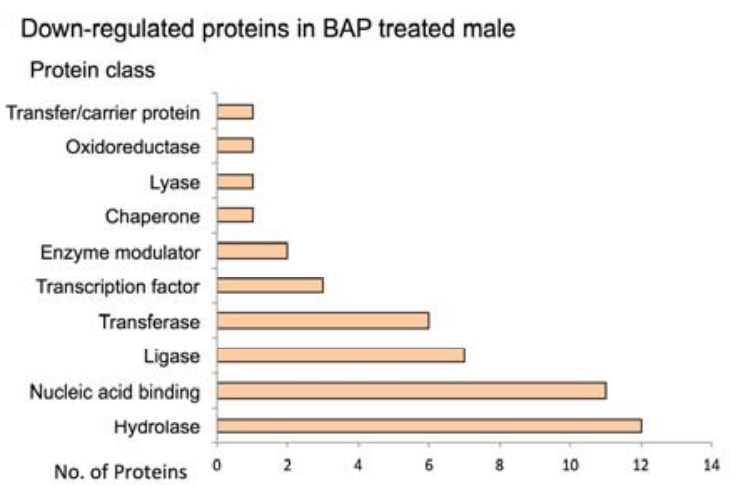

$E$

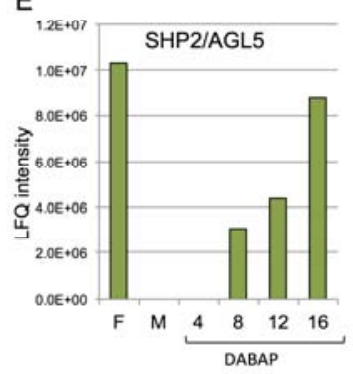

$\mathrm{F}$

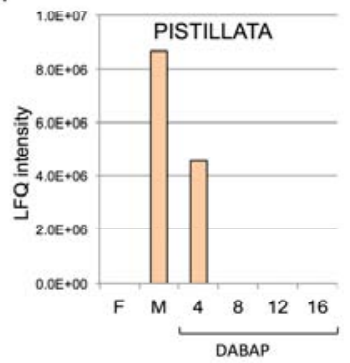


Fig. 3
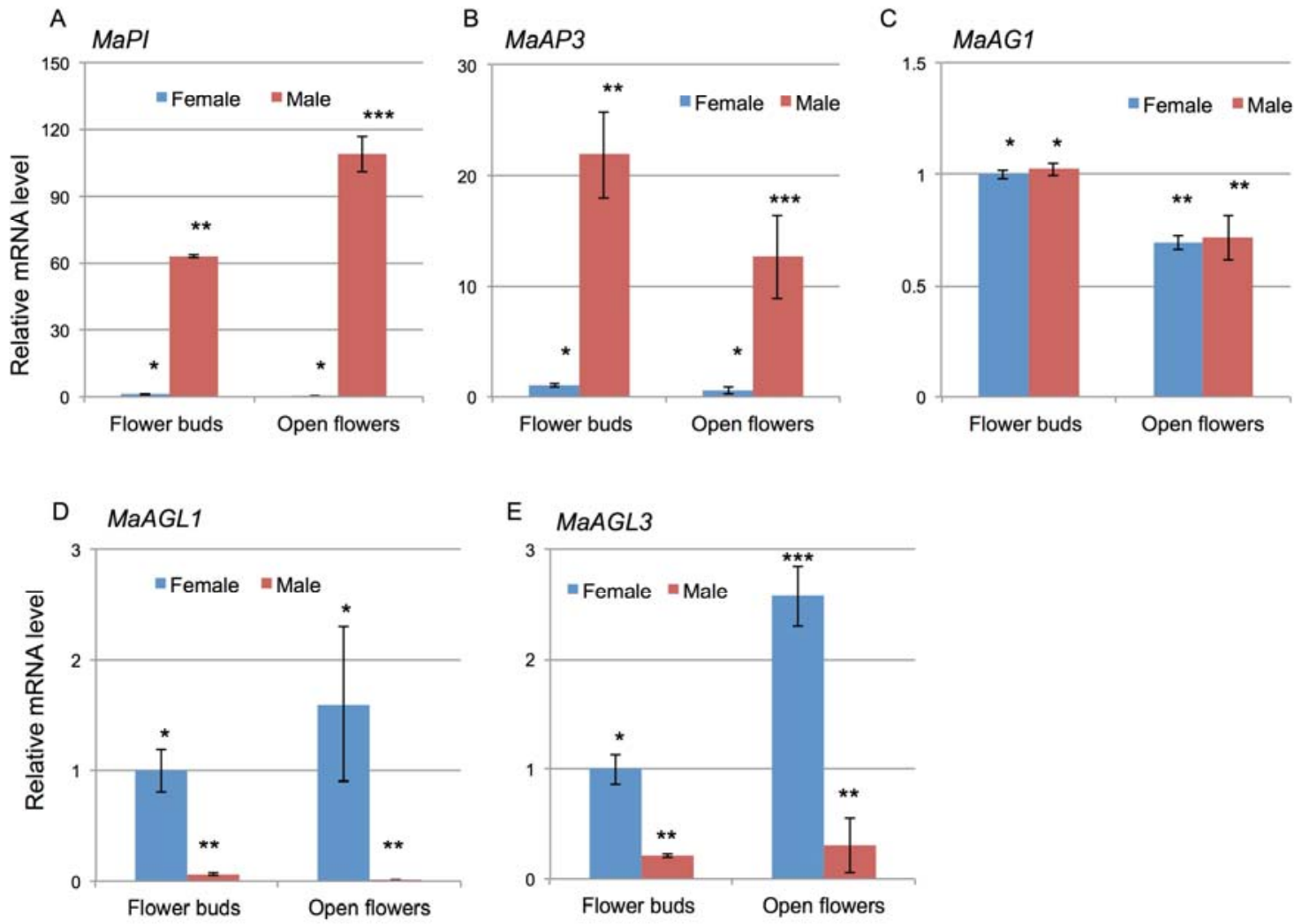
Fig. 4

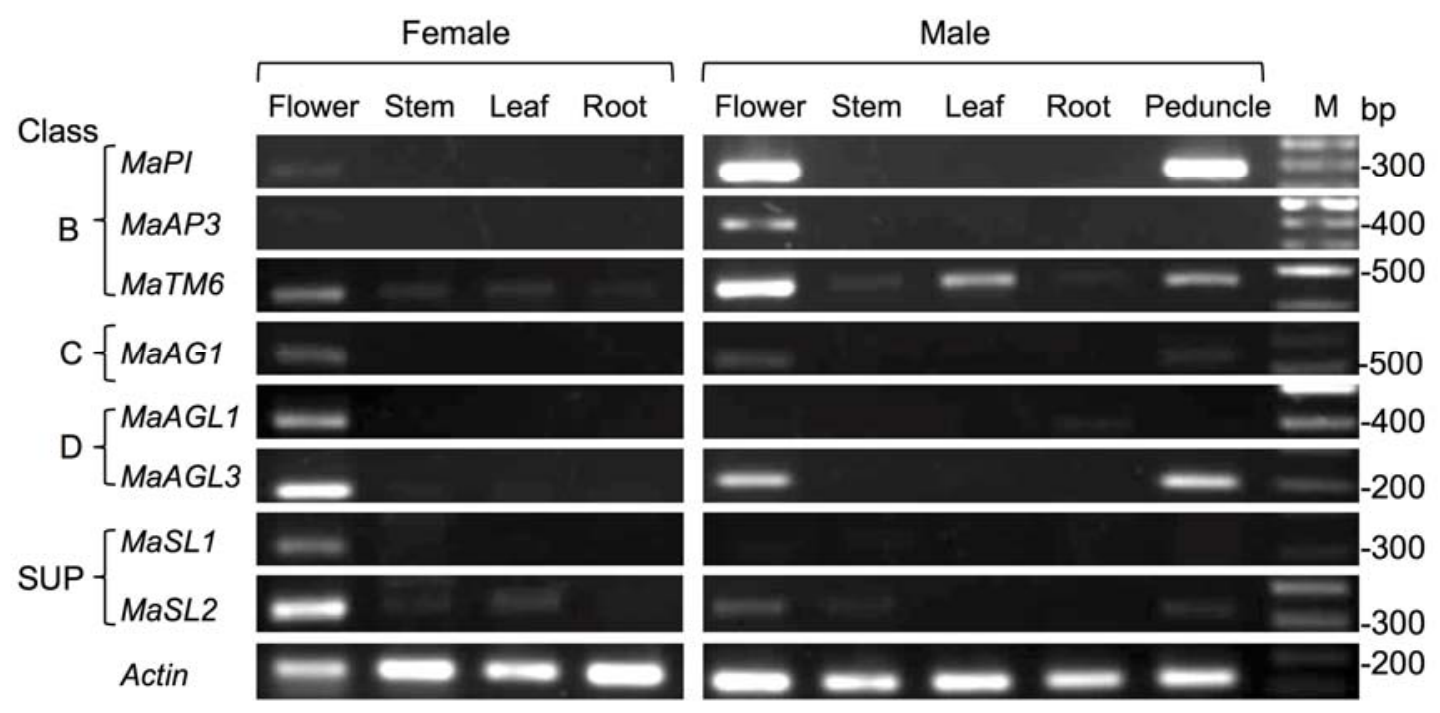


Fig. 5

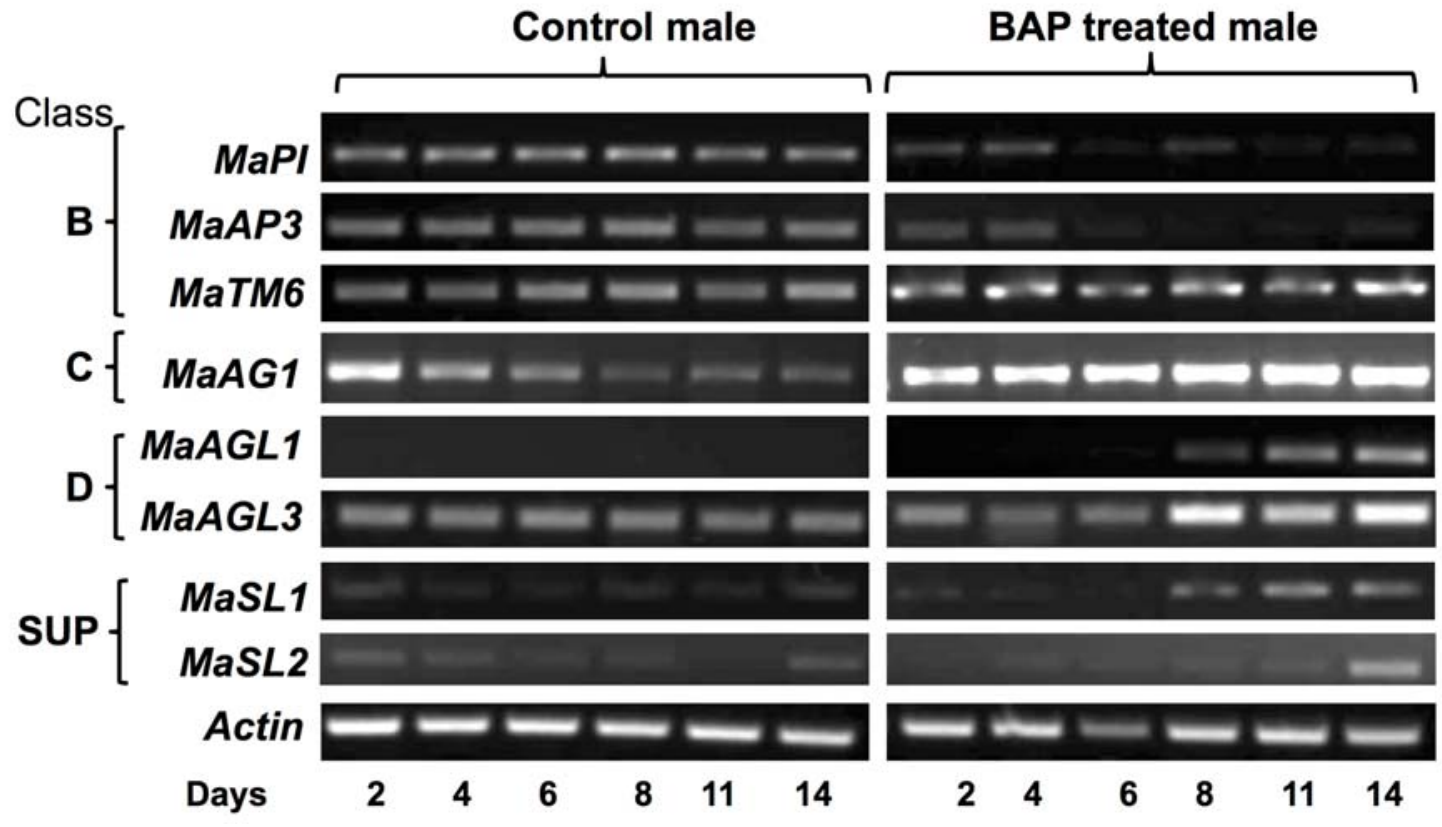


Fig. 6

A

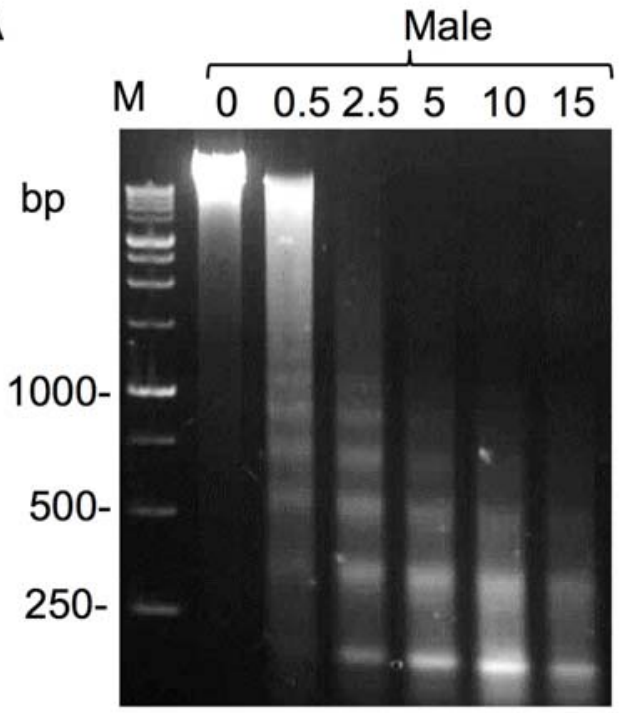

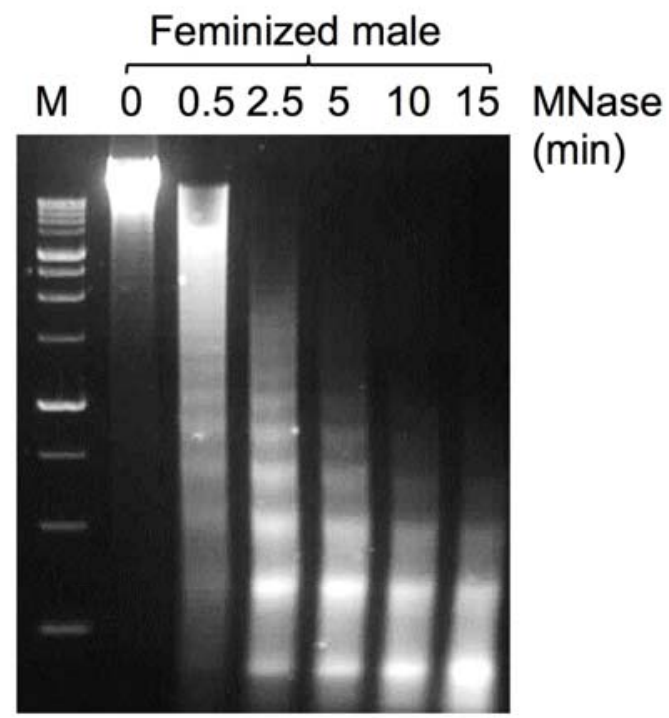

B
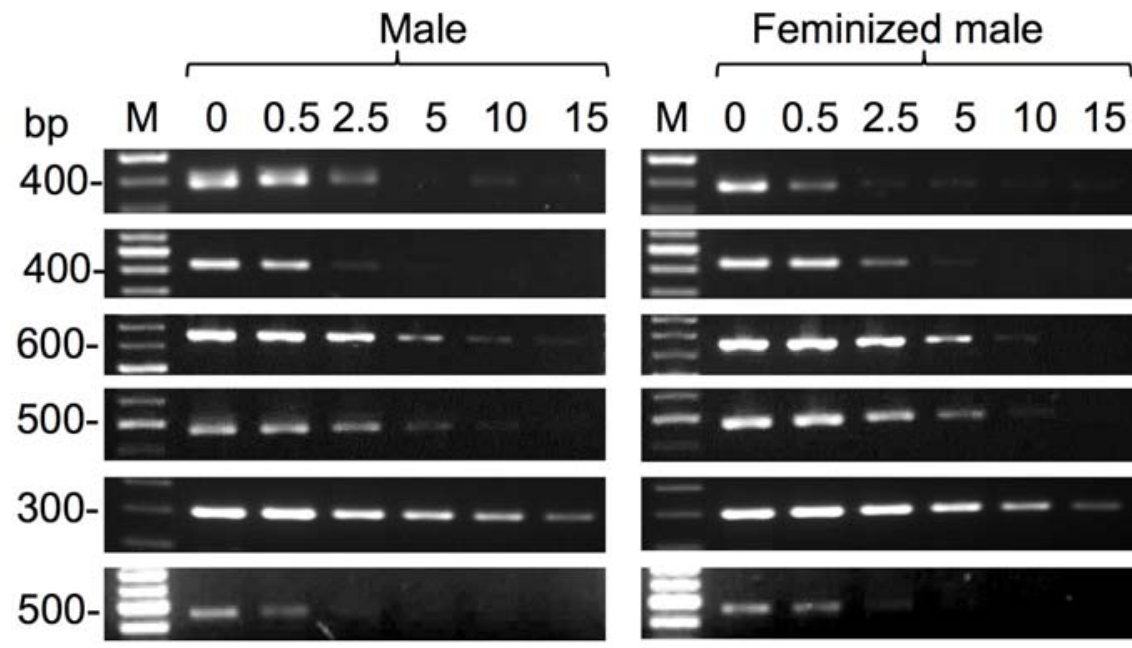

$\min$

MaPI

MaAP3

MaSL1

MaSL2

II

MaAGL1

Actin 
Fig. 7

A

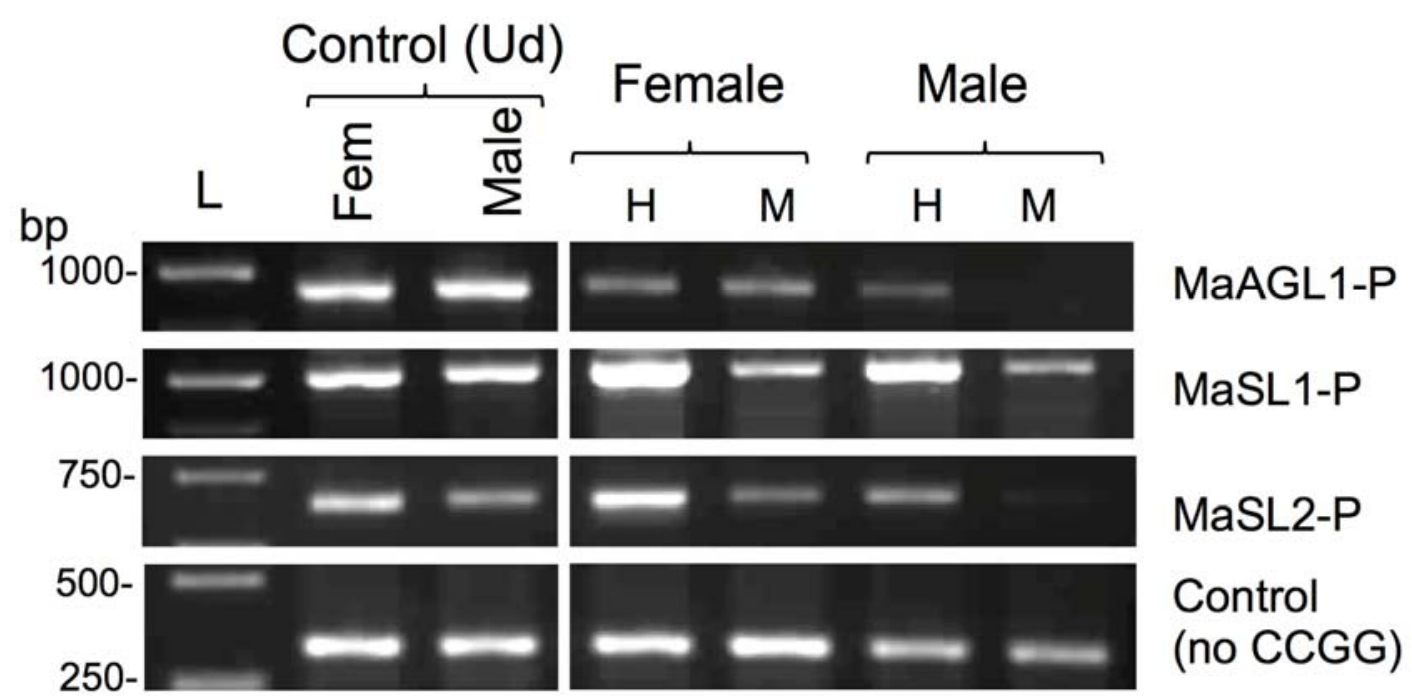

B

Bisulfite sequencing

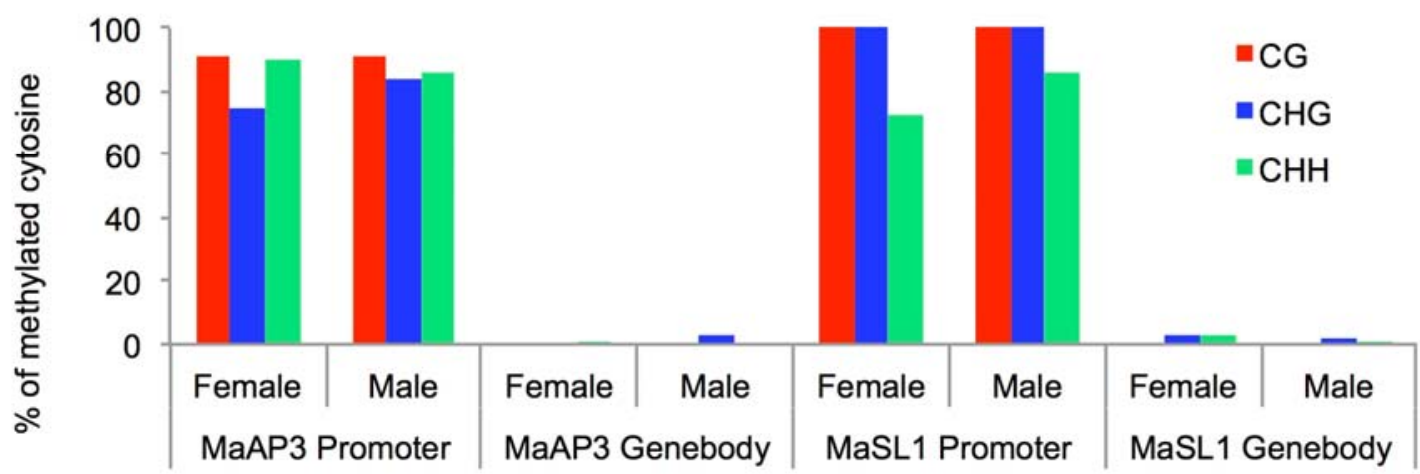




\section{A Up-regulated proteins in BAP treated male}

B

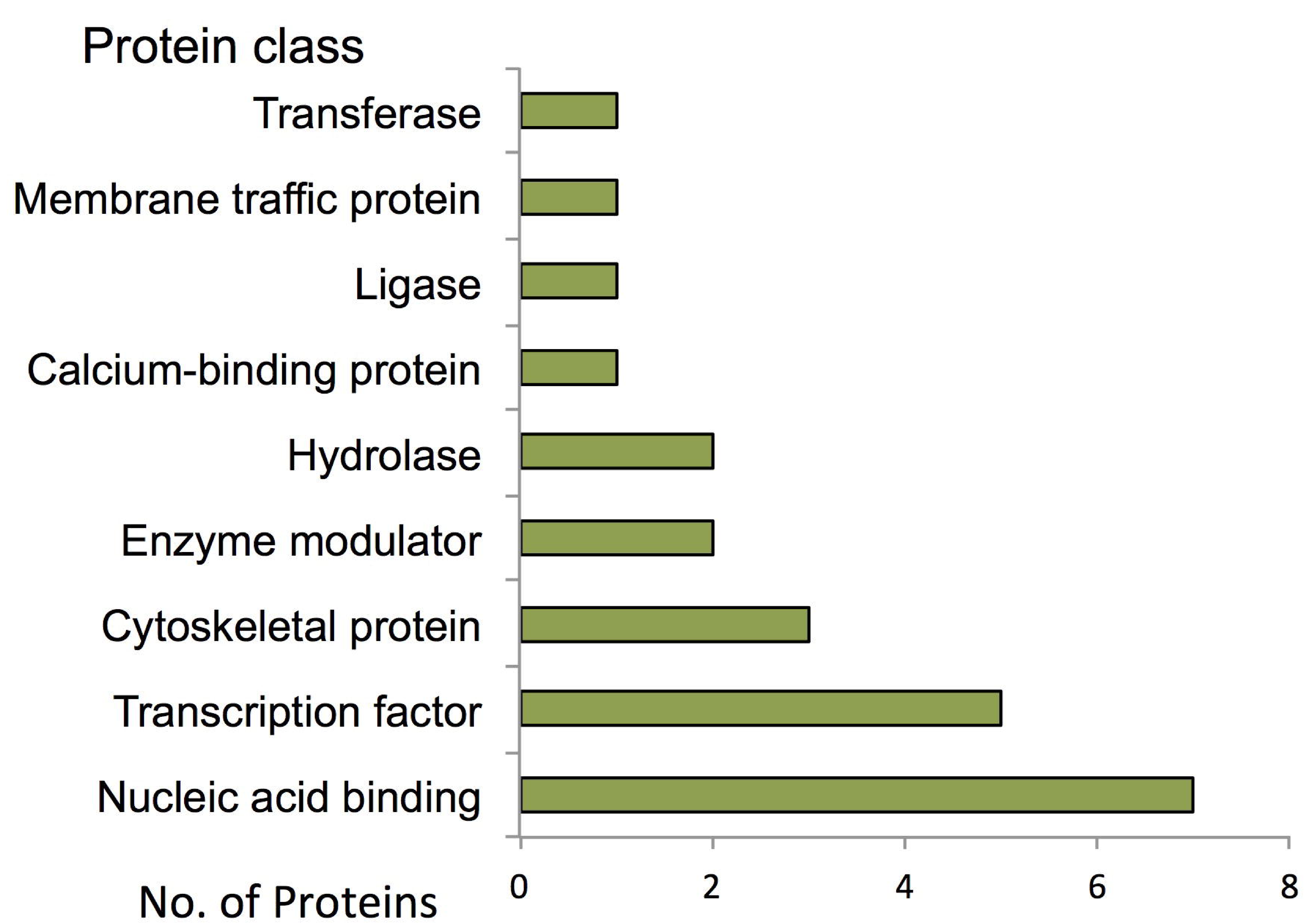

C

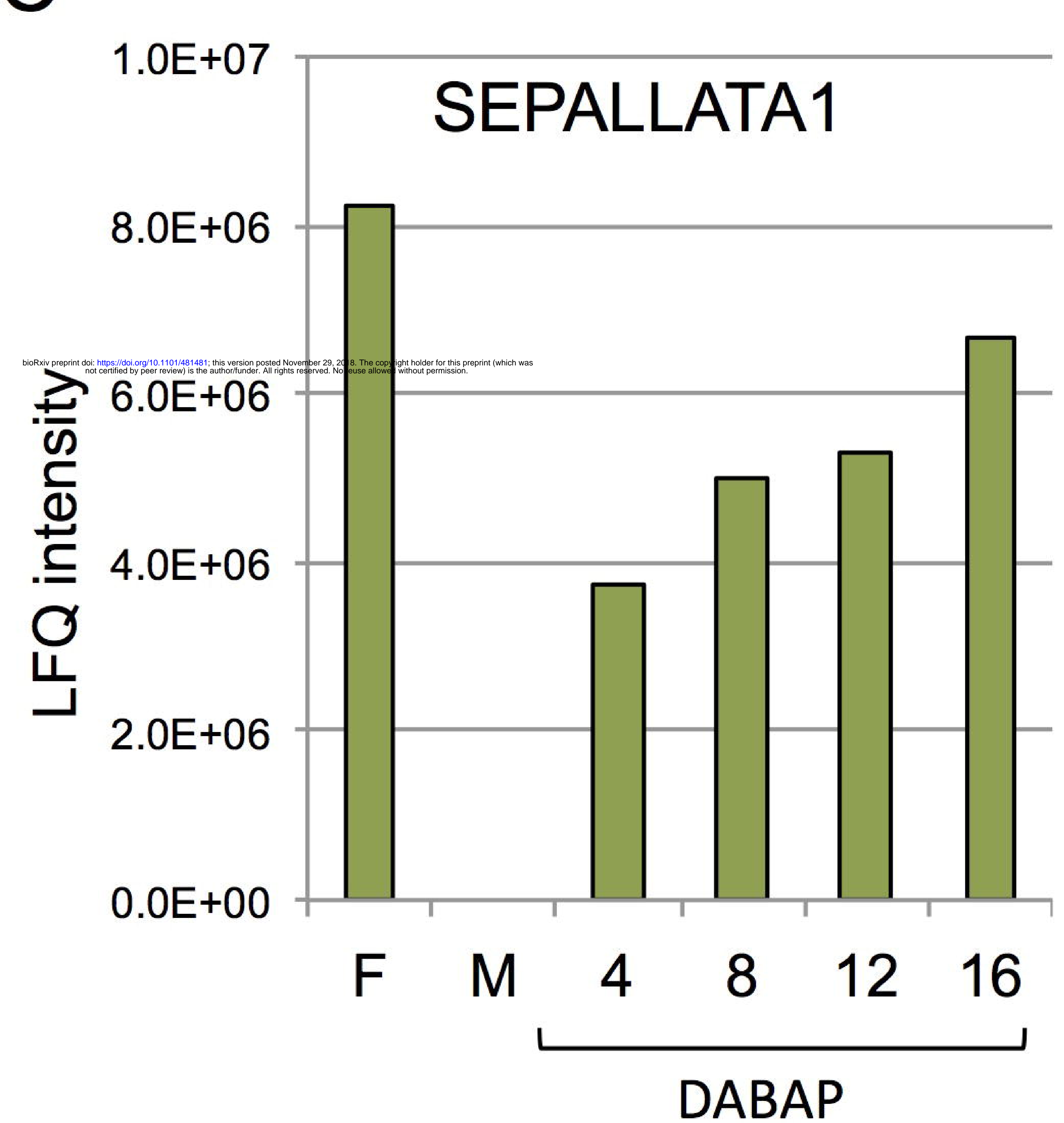

D

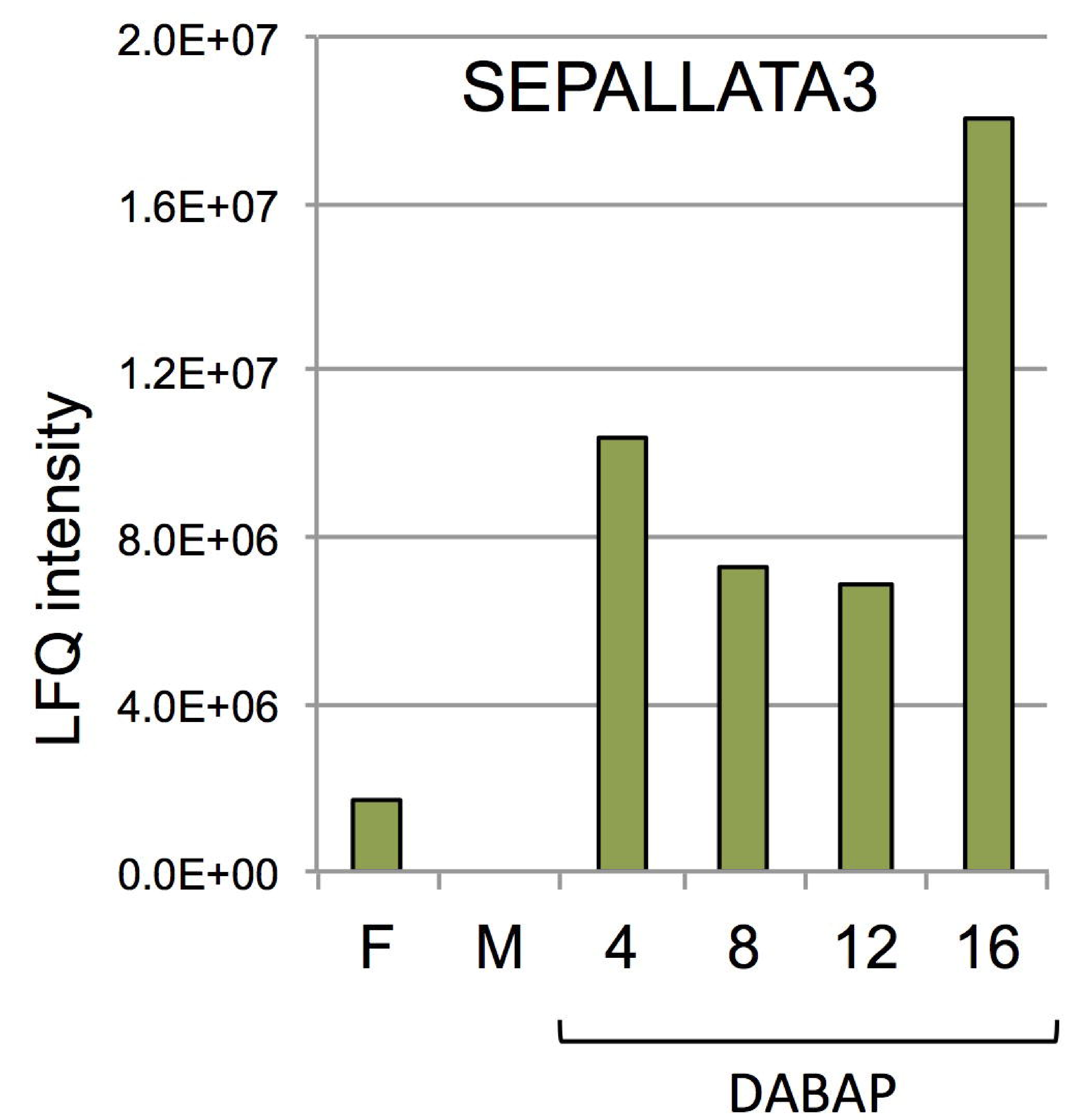

Down-regulated proteins in BAP treated male

Protein class

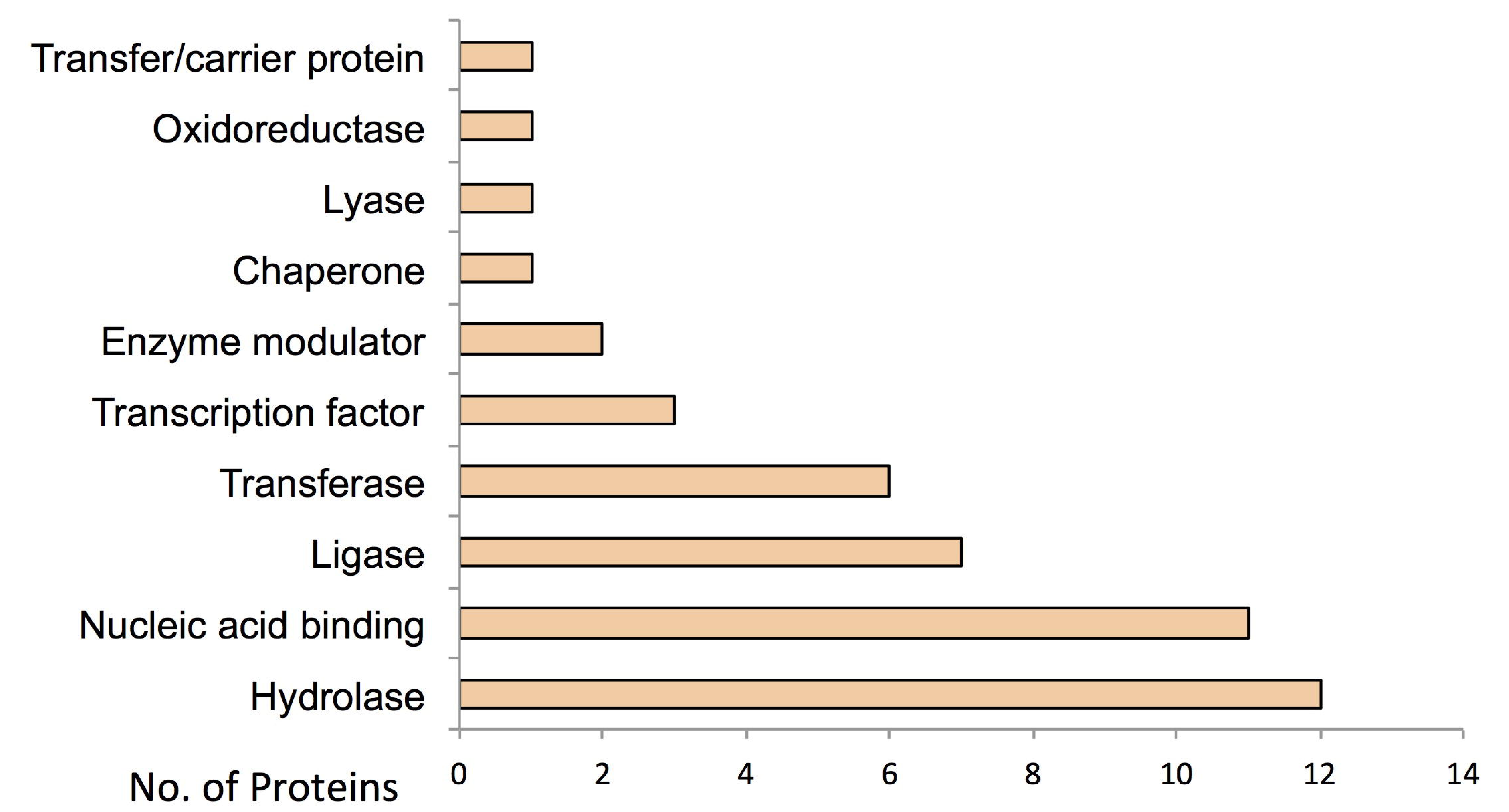

E

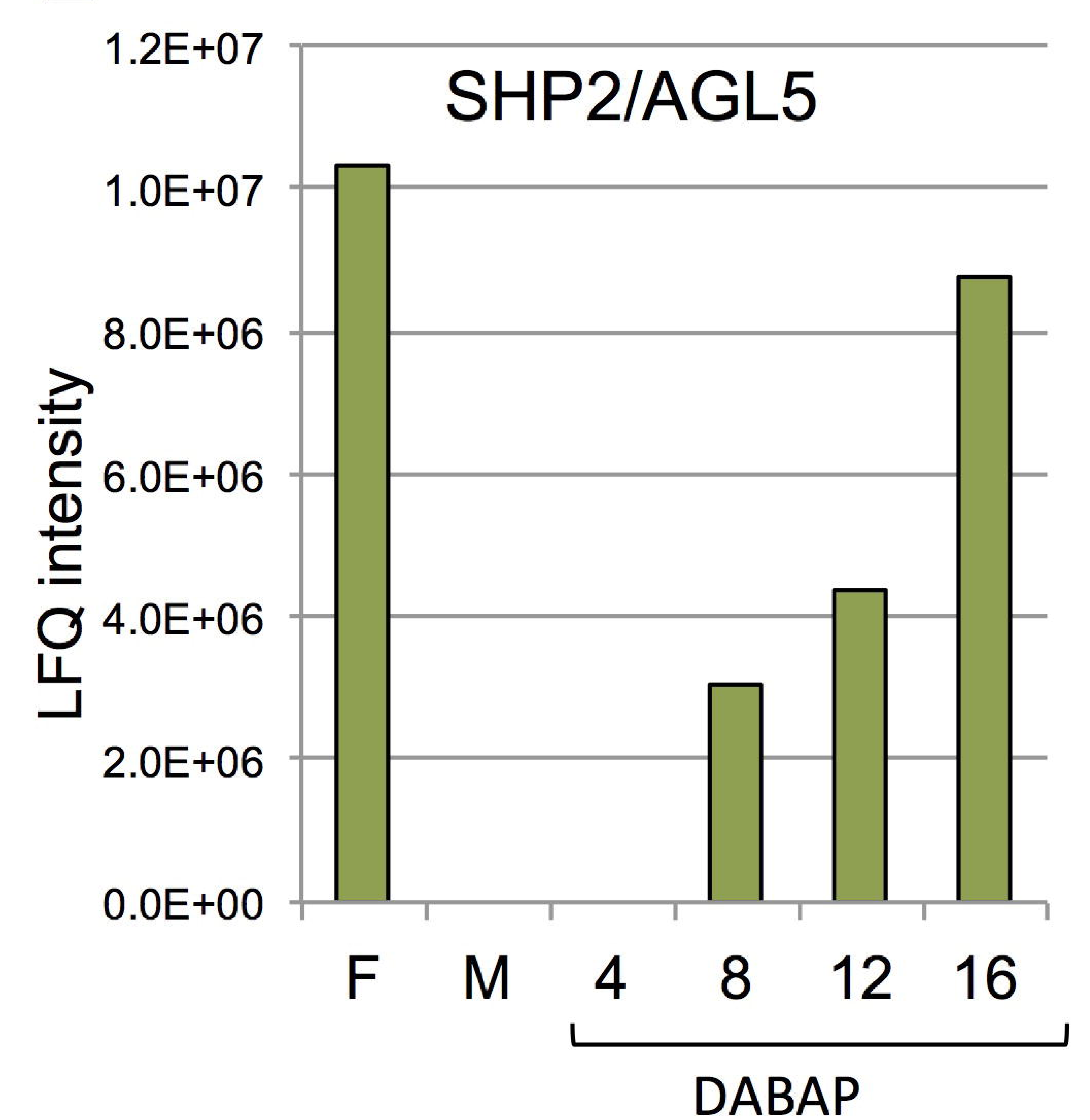

F

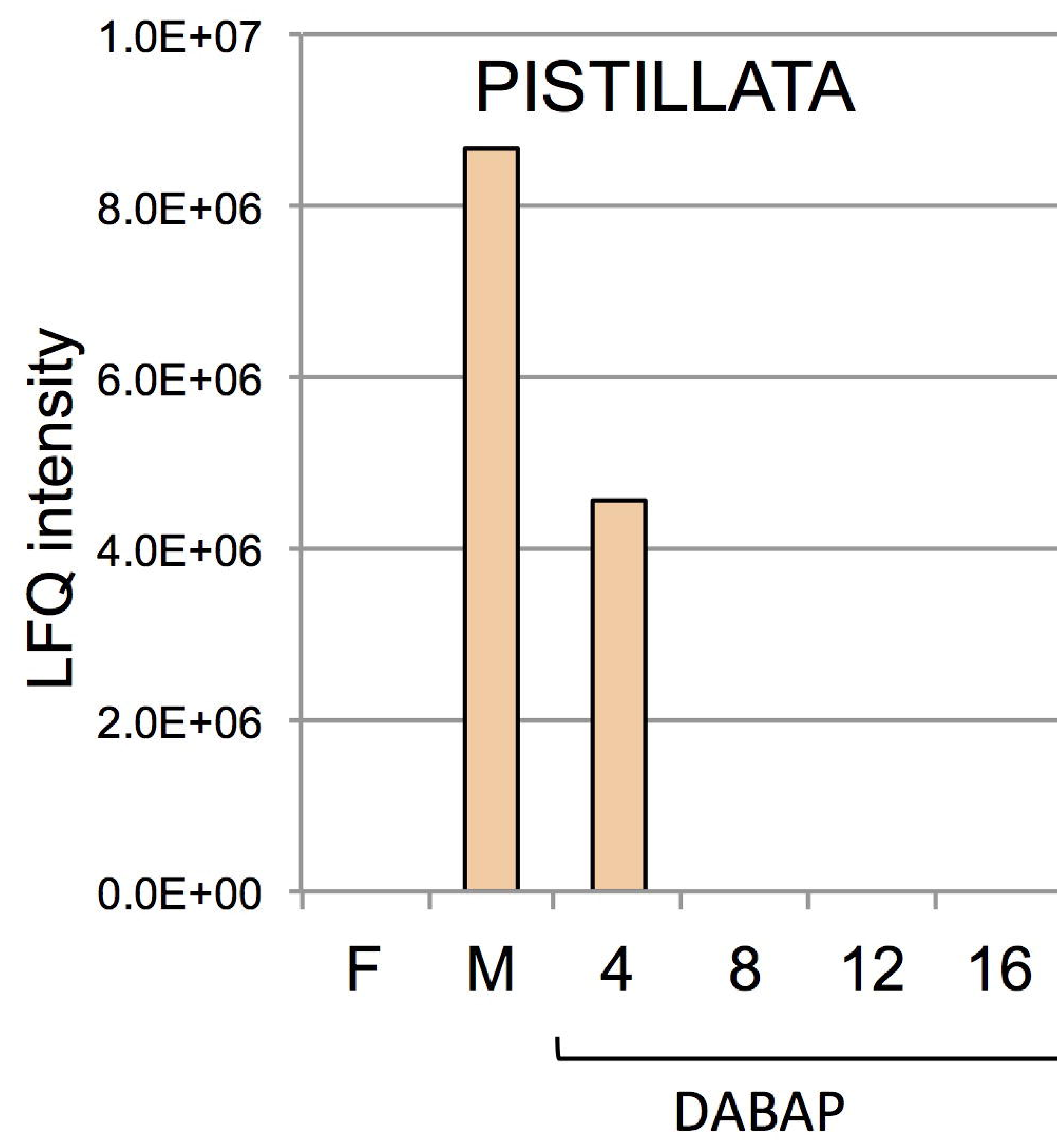



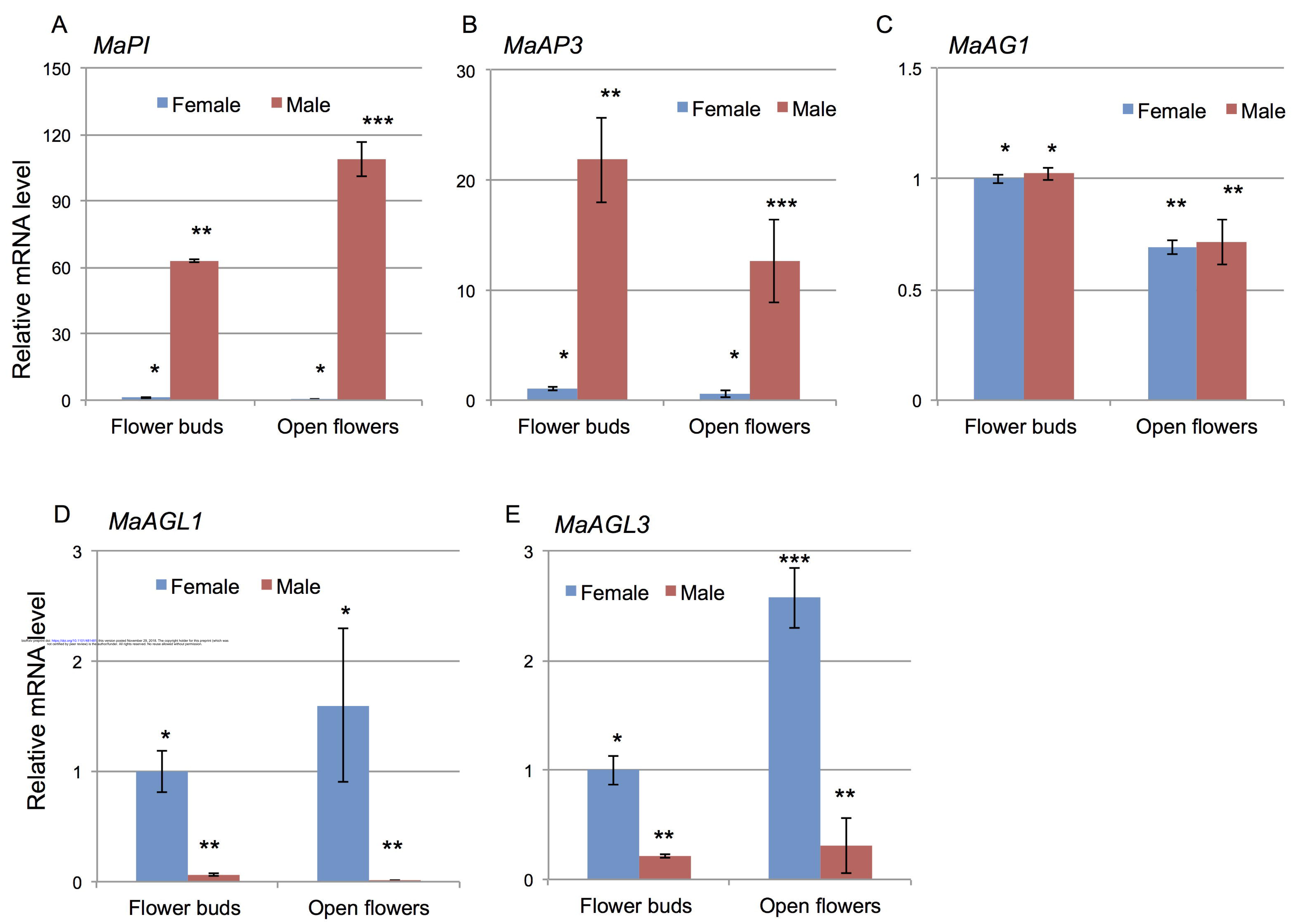
Female

\section{Class}

$\left\{\begin{array}{l}\text { MaPI } \\ \text { MaAP3 } \\ \text { MaTM6 }\end{array}\right.$

C $\{M a A G 1$

$\mathrm{D}\left\{\begin{array}{l}\text { MaAGL1 } \\ \text { MaAGL3 }\end{array}\right.$

SUP $\left\{\begin{array}{l}\text { MaSL1 } \\ \text { MaSL2 }\end{array}\right.$

Actin
Male

Flower Stem Leaf Root Flower Stem Leaf Root Peduncle $M$ bp

$+$

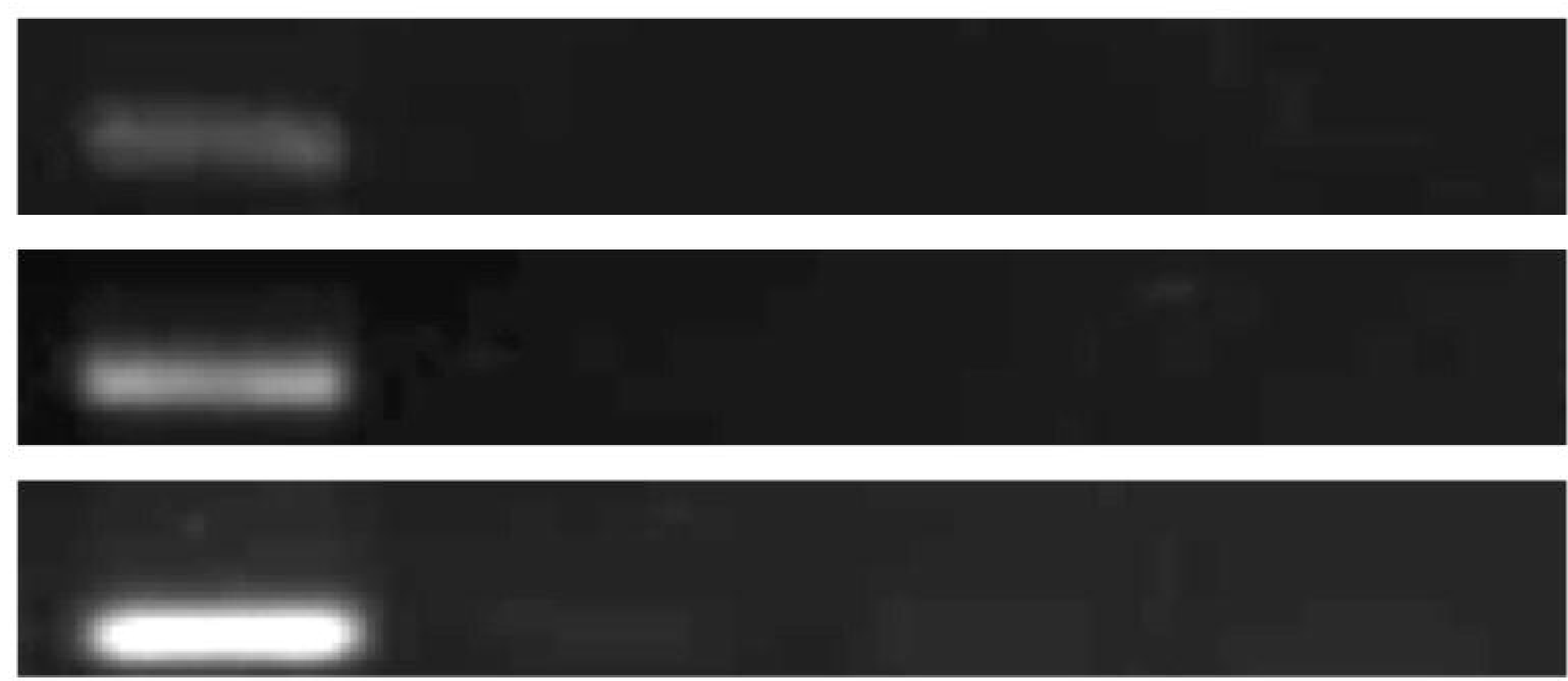

$-300$

$-2=-400$

$\longrightarrow-500$
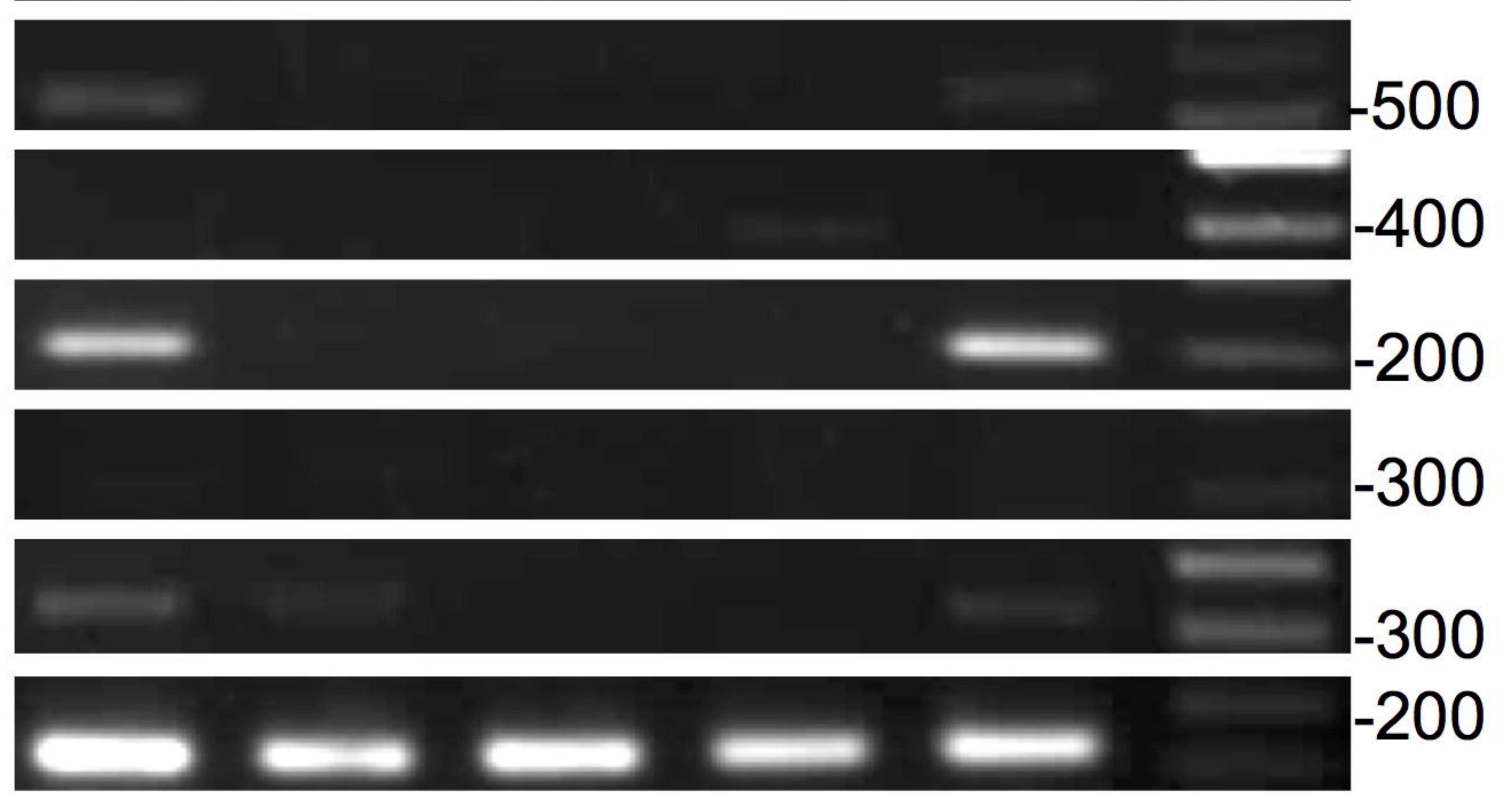
Class

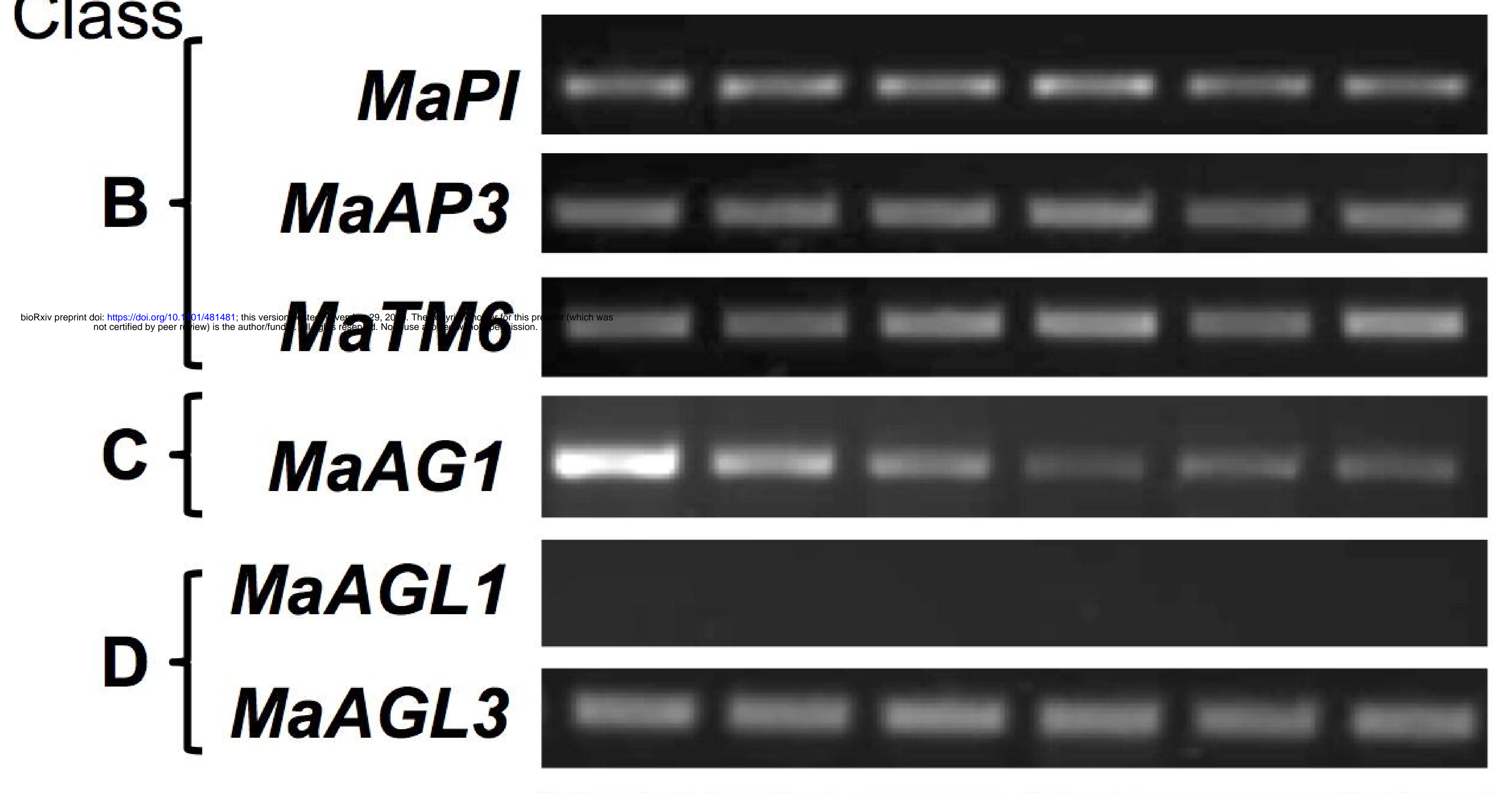

$\operatorname{SUP}\left\{\begin{array}{l}\text { MaSL1 } \\ \text { MaSL2 }\end{array}\right.$

Actin

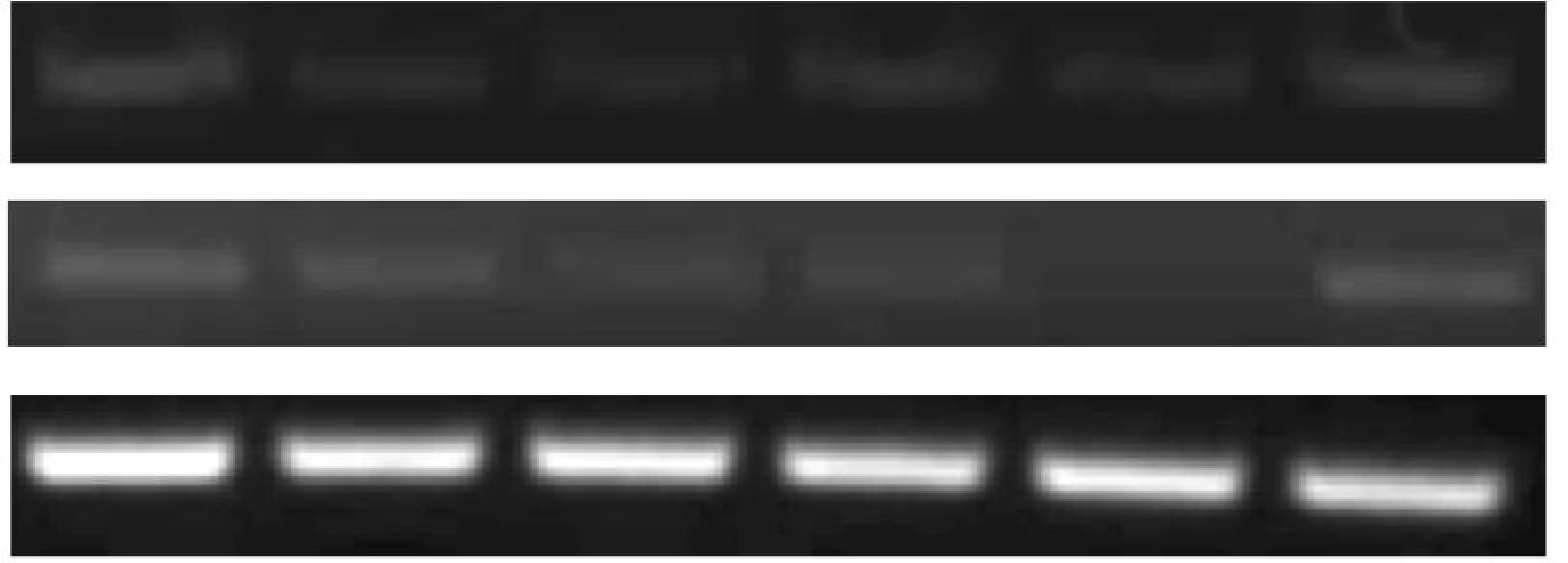

Days

$\begin{array}{llllll}2 & 4 & 6 & 8 & 11 & 14\end{array}$
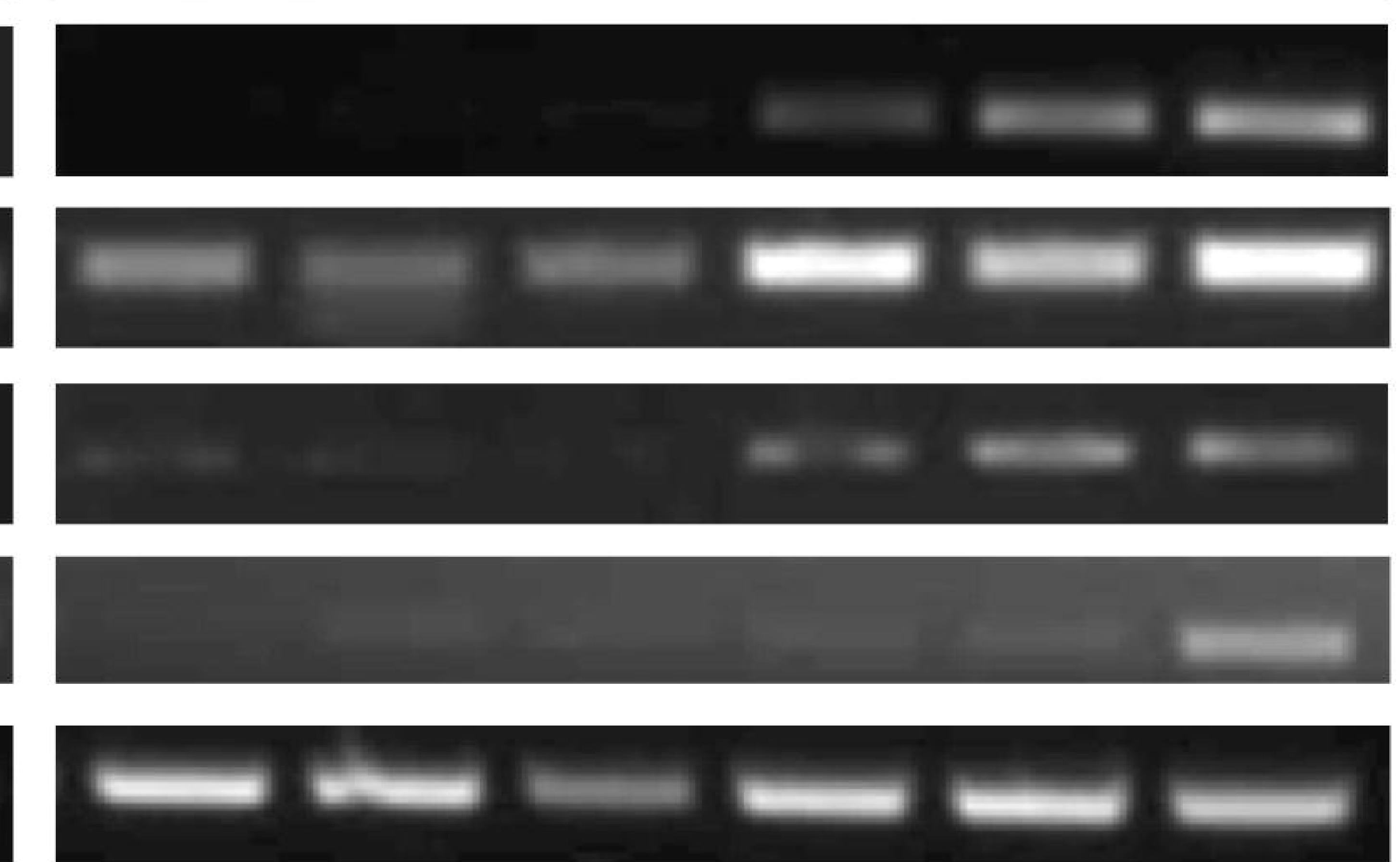

$\begin{array}{llllll}2 & 4 & 6 & 8 & 11 & 14\end{array}$


A

Male

Feminized male

\begin{tabular}{lllllll}
\hline & 0 & 0.52 .5 & 5 & 10 & 15
\end{tabular}

bp

1000-

불 $\rightarrow$

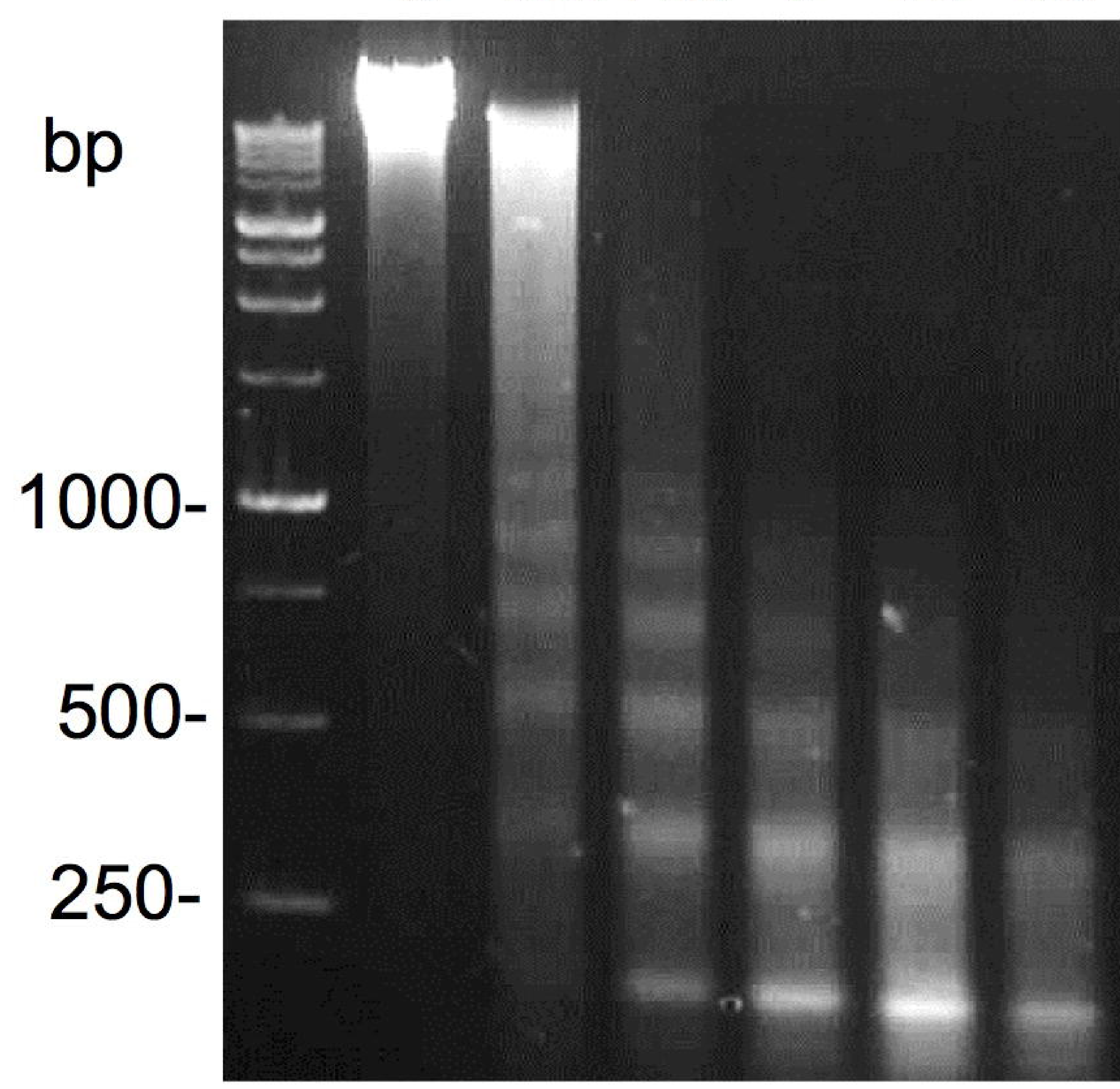

B

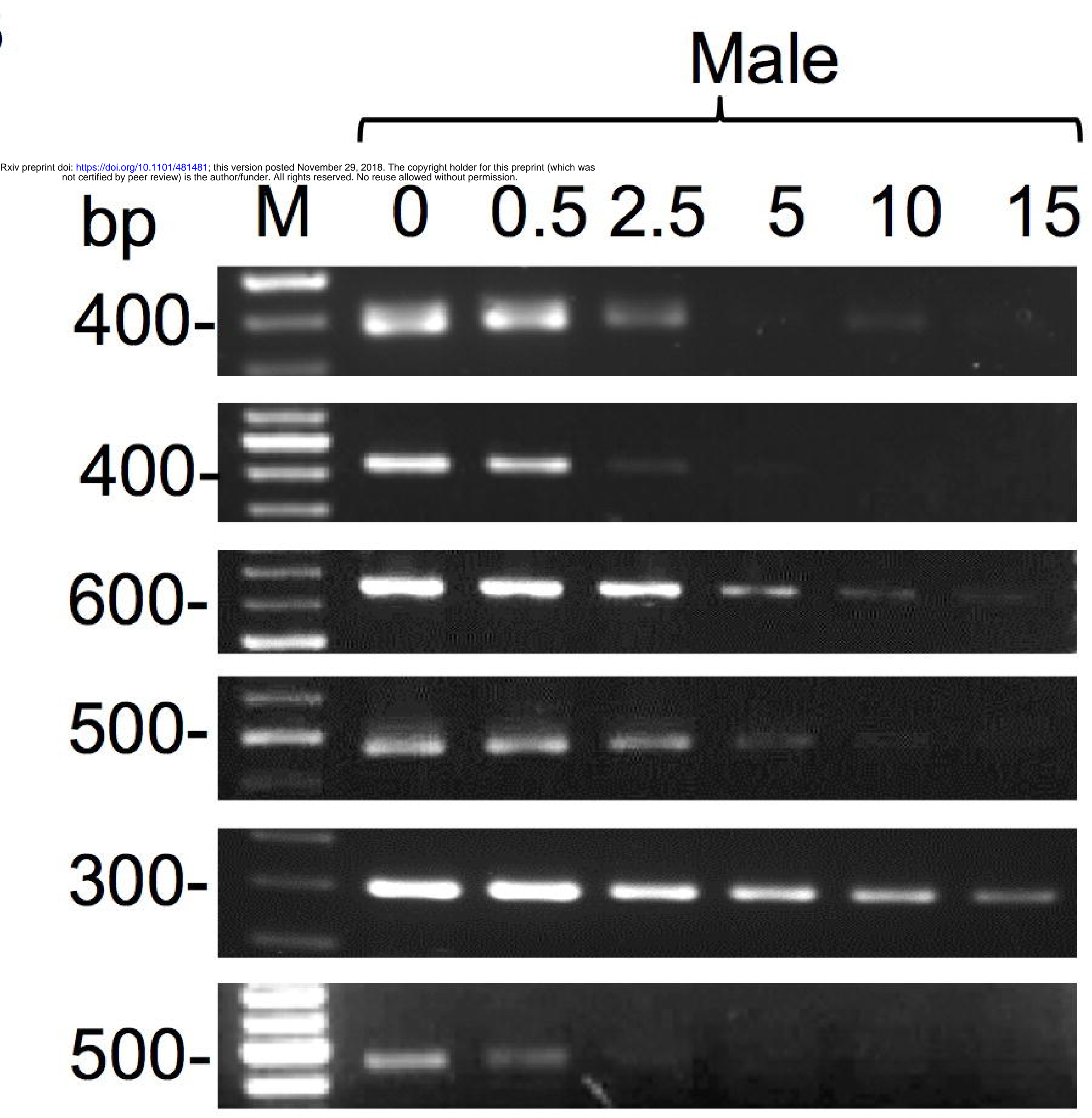

Feminized male

$\begin{array}{llllllll}M & 0 & 0.5 & 2.5 & 5 & 10 & 15 & \mathrm{~min}\end{array}$
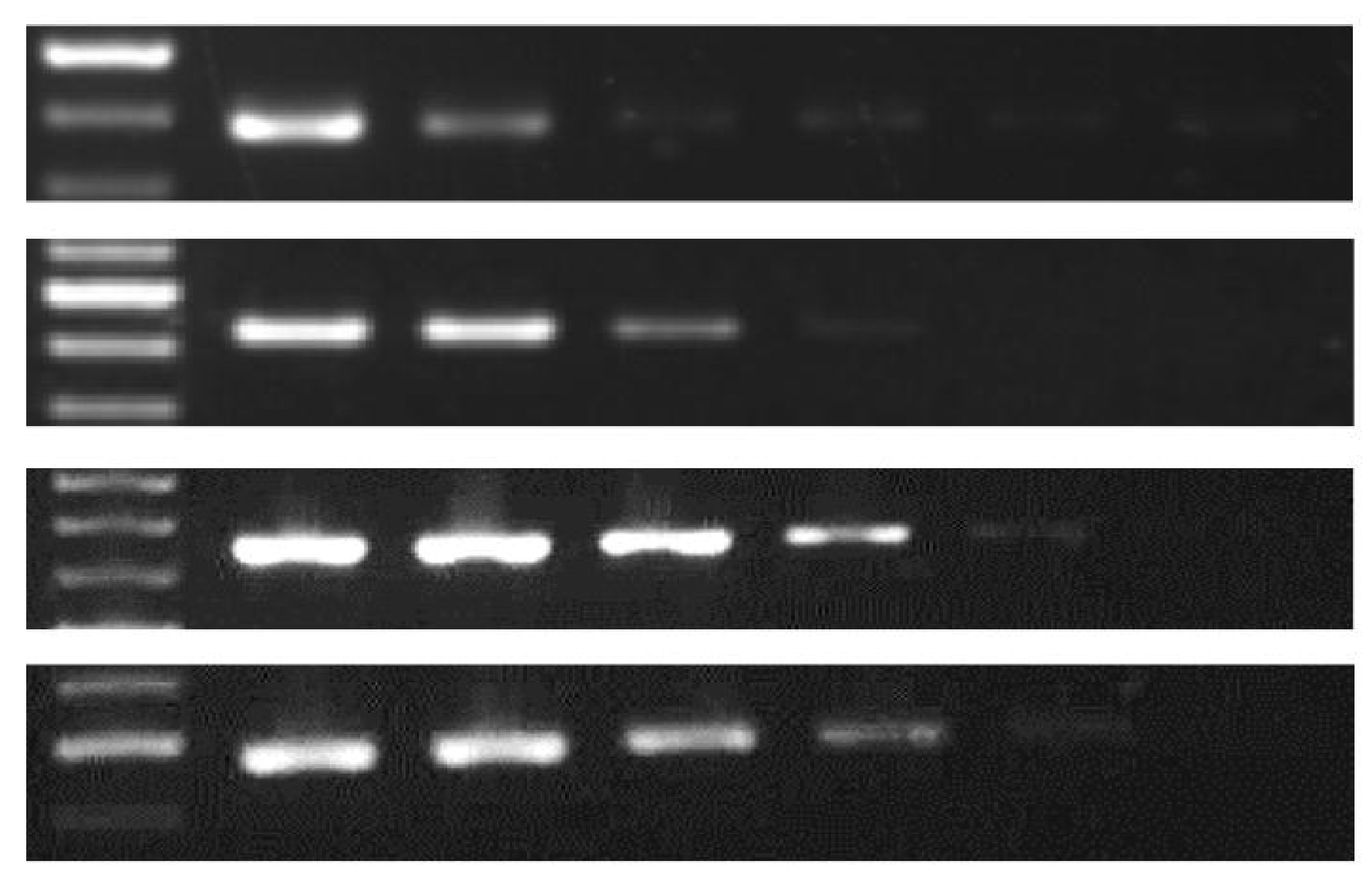

$----$

MaPI

MaAP3

MaSL1

MaSL2
MaAGL1

Actin 


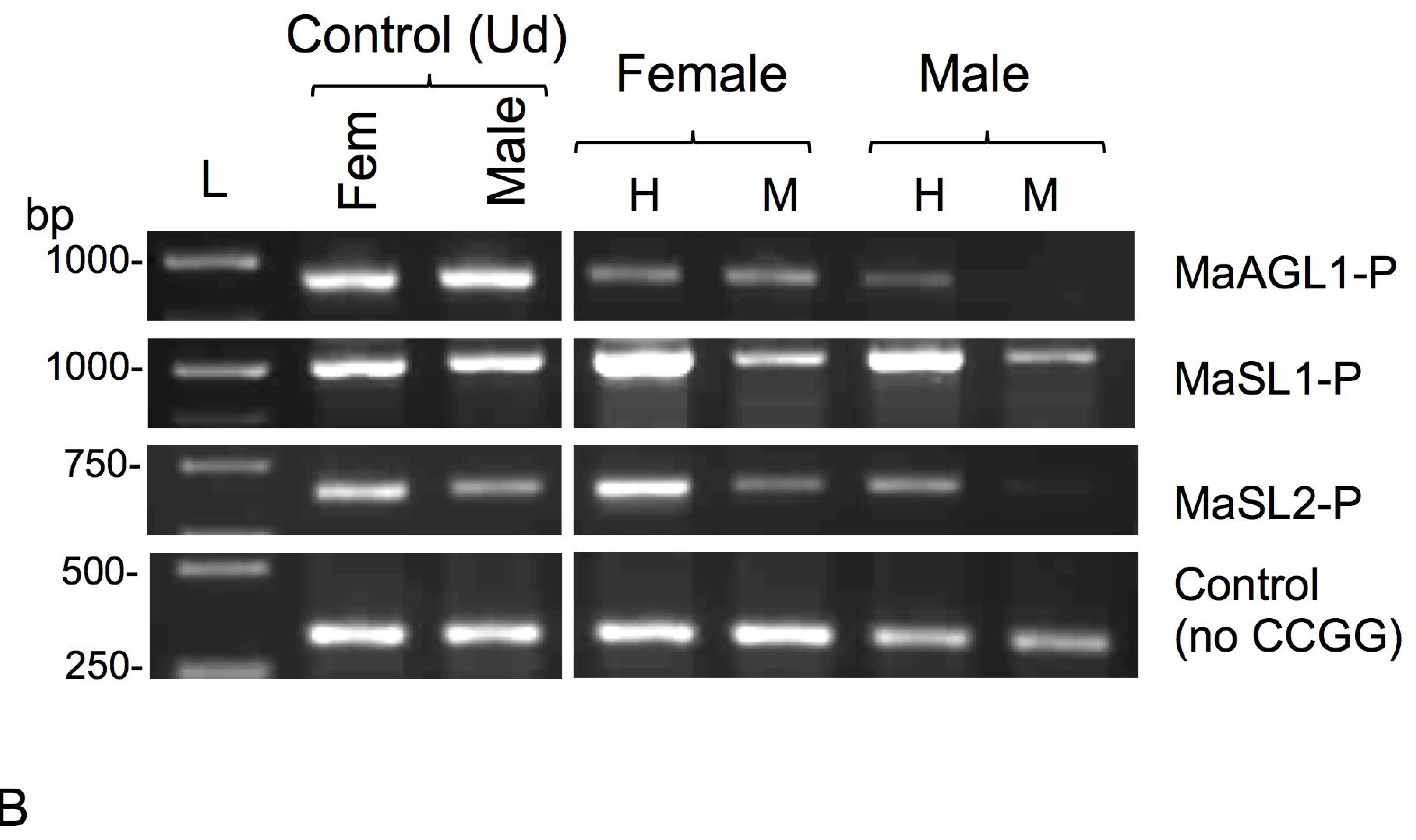

Bisulfite sequencing

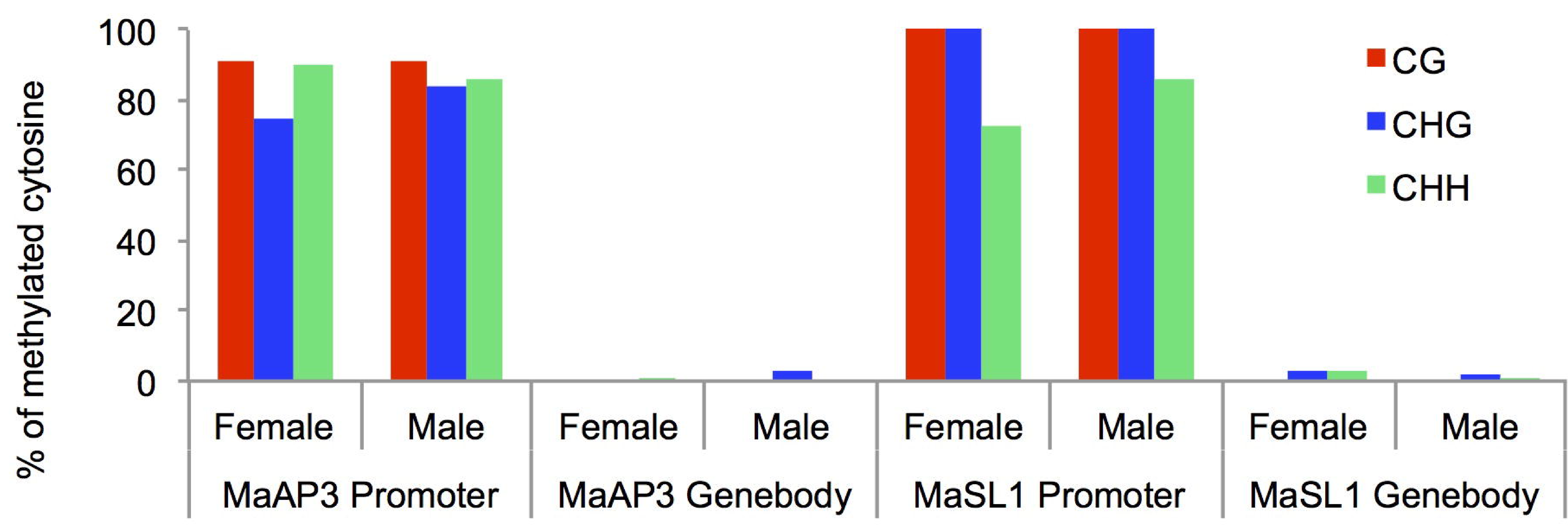

